\title{
WPS3871
}

\section{Does Rising Landlessness Signal Success or Failure for Vietnam’s Agrarian Transition?}

\author{
Martin Ravallion and Dominique van de Walle ${ }^{1}$ \\ Development Research Group, World Bank
}

\begin{abstract}
In the wake of reforms to establish a free market in land-use rights, Vietnam is experiencing a pronounced rise in rural landlessness. To some observers this is a harmless by-product of a more efficient economy, while to others it signals the return of the pre-socialist class-structure, with the rural landless at the bottom of the economic ladder. Our theoretical model suggests that removing restrictions on land markets will increase landlessness among the poor, but that there will be both gainers and losers, with uncertain impacts on aggregate poverty. Empirically, we find that landlessness is less likely for the poor and that the observed rise in landlessness is poverty reducing on balance. However, there are marked regional differences, notably between the north and the south.
\end{abstract}

Key words: Land reform, land markets, poverty, inequality, landlessness, Vietnam JEL codes: D60, P21, Q15

World Bank Policy Research Working Paper 3871, April 2006

The Policy Research Working Paper Series disseminates the findings of work in progress to encourage the exchange of ideas about development issues. An objective of the series is to get the findings out quickly, even if the presentations are less than fully polished. The papers carry the names of the authors and should be cited accordingly. The findings, interpretations, and conclusions expressed in this paper are entirely those of the authors. They do not necessarily represent the view of the World Bank, its Executive Directors, or the countries they represent. Policy Research Working Papers are available online at http://econ.worldbank.org.

\footnotetext{
1 The authors are grateful for the support of the Poverty and Social Impact Analysis initiative of the World Bank’s Poverty Reduction and Economic Management Network and support from the PAPAP Trust Fund. They are also grateful to Martin Rama for encouraging them to write this paper and to Hai Anh Dang for able research assistance. For comments on this paper the authors are grateful to Haroon Akram-Lodhi, Klaus Deininger, Quy-Toan Do, Gershon Feder, Alice Mesnard, Martin Rama, Rob Swinkels, Carrie Turk and seminar participants at the Vietnam Academy of Social Sciences, Hanoi.

Correspondence: Martin Ravallion and Dominique van de Walle, World Bank, 1818 H Street NW, Washington, DC 20433, USA. mravallion@worldbank.org; dvandewalle@worldbank.org
} 


\section{Introduction}

Freeing up agricultural land markets is a risky reform for the transition economies of East Asia, where most of the poor rely on agriculture for their livelihoods. While such a reform is expected to promote economic efficiency, policy makers have worried that it would undo socialism by recreating a rural proletariat — a class of poor rural workers. This concern has inhibited liberalizing agricultural land markets in China, despite the likely efficiency gains. However, other East Asian transition economies, including Vietnam, have nonetheless embarked on this reform and established de facto private ownership of agricultural land.

Starting in the late 1980s, agriculture in Vietnam was de-collectivized and the land was allocated across households by administrative means and in a relatively equitable way (Ravallion and van de Walle, 2004). Since then, legal reforms have supported the emergence of a land market. The 1993 Land Law introduced official land titles and permitted land transactions for the first time since communist rule began. Land remained the property of the state, but usage rights could be legally transferred and exchanged, mortgaged and inherited. Since these reforms, there have been signs of sharply rising rural landlessness, which have fuelled much debate about the wisdom of the reforms.

This paper tries to throw new light on the questions that lie at the heart of the current concerns about rising landlessness in rural Vietnam. Is the country heading toward a South Asian style of rural development in which there is a large and unusually poor landless class? Or are farmers simply selling their land to pursue more rewarding activities? In short, does rising rural landlessness in the wake of market-oriented reforms signal an emerging new poverty concern for Vietnam, or is it simply a by-product of the process of poverty reduction? 
We begin by reviewing the ongoing debate on land markets in the transition economies of East Asia. Then we address a key issue in that debate: Is rising rural landlessness retarding the country's progress against poverty? Section 3 uses a simple model of occupational choice to see how we might expect both landlessness and poverty to be affected by introducing a land market. We then turn to various empirical methods. After describing our data in section 4, we study the evolving relationship between landlessness and living standards in section 5. Section 6 notes some aspects of how participation in labor and credit markets has changed. The role played by rising landlessness in reducing poverty is examined in section 7. Section 8 concludes.

\section{The debate on land market reform in East Asia}

Similarly to China’s "household-responsibility system” introduced in the late 1970s, Vietnam returned decision-making powers over farm outputs to households in the early 1980s. In both countries, the farm-household became the residual claimant on all output in excess of its contracted quota, with the collectives and local cadres setting those quotas and allocating land across households for fixed periods; households were not free to transfer, exchange or sell their allocated land. It is widely agreed that this major agrarian reform increased agricultural output in both countries (see the survey by Rozelle and Swinnen, 2004).

However, agrarian policies in the two countries diverged from the late 1980s. In China, the collectives retained their powers in setting quotas and allocating (and re-allocating) land. ${ }^{2}$ There have been concerns about the efficiency costs of China's non-market land allocation (Li et al., 1998; Carter and Estrin, 2001; Brümmer et al. 2006). By contrast, Vietnam allowed a free market in land-use rights, with the state retaining formal ownership. This was done in two stages. In the first, land was assigned to households. While this appears to have been done in a

2 The history of China's (rural and urban) land policies is reviewed in Ho and Lin (2003). 
relatively equitable way — giving everyone within the commune roughly the same irrigated-land equivalent — some households ended up with more land than in a competitive market allocation, while others had less (Ravallion and van de Walle, 2004). The administrative allocation also left considerable fragmentation of holdings (as small, dispersed plots), with possible efficiency costs (Lam, 2001). ${ }^{3}$ In the second stage, and in response to the inefficiencies in the administrative allocation, Vietnam's 1993 land law essentially introduced a free market in land-use rights — de facto private ownership of land as a marketable commodity. ${ }^{4}$

Supporters of Vietnam's reform argued that it will increase aggregate output, by allowing land to be re-allocated toward more efficient farmers. Hayami (1994) saw Vietnam’s 1993 land law as the key step toward more efficient agriculture, asserting that “... it is not necessary to be overly concerned about an inequitable agrarian structure emerging” (p.15). Ten years later, the Hanoi-based Center for Rural Progress (2004) argued that an active land market in the Mekong Delta contributed to more rapid poverty reduction by allowing more efficient farmers to accumulate more land, fostering diversification and increasing farmers’ access to credit. ${ }^{5}$ There is evidence that land allocation has become more efficient since the 1993 land law. Deininger and Jin (2003) found evidence that more able farmers acquired more land after the reform. Ravallion and van de Walle (2005) found that agricultural land was re-allocated in a way that attenuated the initial inefficiencies in the administrative assignment of land at the time of de-collectivization; households that started with an inefficiently low (high) amount of crop land under the administrative assignment tended to increase (decrease) their holdings over time.

3 The fragmentation arose to assure that each member of the commune got both good quality and low quality land. Thus it may entail gains to equity and help share risks.

$4 \quad$ Other reforms included freeing up the markets for inputs and outputs. Benjamin and Brandt (2004) find no evidence that these reforms put upward pressure on rural consumption inequality, 1993-98. 5 These claims are based on largely informal interviews with local authorities and a small number of households; the selection process for the latter appears to have favored places where the land reforms were more successful; see the discussion in section 2.2 (esp. p.2-4) of Center for Rural Progress (2004). 
Ravallion and van de Walle (2005) also found evidence of polarization among those who started off with too little land; while most of these households acquired more land, a minority sold or transferred all their farmland, possibly to take up other non-farm activities or to pay off debts. Landlessness stemmed in part from inefficiencies in the initial administrative allocation.

A reform that first equalized holdings of such an important asset and then made it a market good might be expected to be highly pro-poor. However, a number of critics have argued instead that Vietnam’s agrarian strategy has exacerbated long-term poverty by promoting rural landlessness. We call this the poverty-increasing landlessness effect (PILE). A report by

ActionAid captures well the seemingly widespread concerns that the new law would lead to:

“..a greater concentration of land ownership, a greater disparity in wealth throughout the rural community and a possible increase in the phenomenon of landlessness and full-time agricultural wage labour.” (Smith and Binh, 1994, p.17.)

Writing over 10 years later, Akram-Lodhi $(2004,2005)$ argues that Vietnam's reforms have not been pro-poor but have created "peasant class differentiation" (p.107):

"The evidence...demonstrates the rapid growth of a class of rural landless who are largely separated from the means of production, who survive by intermittently selling their labour, and who are the poorest segment of rural society.” (Akram-Lodhi, 2005, p.73)

Similarly, Zhou (1998) argues that the privatization of land-use rights in Vietnam, Cambodia and

Laos have been detrimental by fostering rural landlessness and urban slums. Zhou sees the rise in rural landlessness in Vietnam as a vindication of the Chinese policy: ${ }^{6}$

“..the fact that new landlessness has appeared immediately after the land tenure reform in the low wage economy of Cambodia, Laos and Vietnam already shows that this model is inferior to the Chinese.” (Zhou, 1998, p.19)

This echoes Dong’s (1996, p.918) argument (also in defense of China’s land policy) that:

“...the distribution of land among peasants must necessarily be equal so as to meet their basic needs in life and to enhance their employability. Otherwise the landless and near-landless will suffer from malnourishment...”

$6 \quad$ Zhou aims to refute Hayami (1994) who argued that introducing a free market in land would promote more efficient agriculture in the transition economies of East Asia. Also see Zhou (2001). 
Critics of land-markets have been concerned that the poorest become landless and (hence) dependent on wage labor, which (it is believed) makes them worse off. This view stems in part from a mistrust of labor markets. For example, in coming to the conclusion summarized above, Dong alludes to an efficiency-wage argument (citing Dasgupta and Ray, 1986, and Moene, 1992), whereby workers with too few assets end up unemployed in equilibrium (although Dong does not establish that the poor would be better off without land markets).

Another concern relates to "induced effects" of land-markets, in which local institutions play an important role. The commune's control over land came with responsibilities to help with non-land inputs and providing certain social services, including insurance. With a land market, farmers were increasingly left to their own devices; with their land being marketable it was felt that they could use it as collateral to obtain credit or sell some or all of it to cope with shocks. The retreat of the local state from its traditional welfare role has been a prominent concern for critics of the land-market reforms. ${ }^{7}$

The interaction between the land markets and local governance has also been an issue. The expropriation of agricultural land by the local state in the process of land-use conversion has often entailed protests by expropriated farmers who feel that they have not received fair compensation. It is often claimed that it is the poor who incur the largest costs; for example, Yeh and Li (1999) and Guo (2001) argue that poor farmers in China are inadequately compensated for land expropriations. ${ }^{8}$ Vietnam's greater reliance on markets for land allocation might be expected to help in setting fair prices. However, the local state in Vietnam continues to play an active role in setting the terms of land-use conversions and there have also been numerous

\footnotetext{
$7 \quad$ See for example the discussions in Smith (1997) and de Mauny and Vu (1998).

$8 \quad$ Concerns about these issues have been prominent in high-level policy discussions within China and in the international press (see, for example, The Economist, 2006, and Yardley, 2006).
} 
protests by poor farmers about inadequate compensation and claims of misconduct by local officials in charge of the conversion process (see, for example, Nguyen, 2004a).

Heterogeneity in impacts can be expected. Historical differences entailed that the market economy was more developed in the Mekong Delta and the South-East (the region around Ho Chi Minh City) than the north. ${ }^{9}$ More deeply entrenched traditions of collectivized agriculture in the north are likely to have created lower initial inequality in some key dimensions than found in the south. The distribution of land was more equal in the north. ${ }^{10}$ It is also likely that non-land inputs to farming were more dependent on own wealth in the south (Akram-Lodhi, 2005). The pressures toward further land consolidation are likely to be stronger in the south. ${ }^{11}$

Labor markets also differed. For this study, a key stylized fact is that farmers in the north are likely to have faced more remunerative options for supplying skilled labor than found in the south. The wage regressions reported by Gallup (2004) (for 1998) indicate appreciably higher returns to schooling in the rural north than the rural south. There is a corresponding schooling gap between the north and the south. ${ }^{12}$ We calculate (from the surveys described later) that mean years of schooling in 1993 was 7.3 years for farm-households in the north’s Red River Delta (RRD) versus 4.3 years in the south's Mekong Delta (MD). ${ }^{13}$ It is also likely that aggregate demand for agricultural labor has been stronger than in the north, given the south's larger farms and higher agricultural growth rate in the 1990s (Benjamin and Brandt, 2004).

\footnotetext{
9 After re-unification in the mid-1970s, farmers in the MD had resisted collectivization, and by the time the country de-collectivized in the late 1980s, less than $10 \%$ of all of the region's farmers had been organized into collectives. By contrast, virtually all of the crop land in the north and the south's Central Coastal region was collectivized by that time (Pingali and Xuan 1992; Ngo 1993).

10 In 1992/93, the coefficient of variation in the log of annual agricultural land was $8.3 \%$ in the North's Red River Delta, versus 15.3\% in the south's Mekong Delta (Ravallion and van de Walle 2004). 11 This is consistent with the observations made by Taylor (2004), based on field work in the MD. 12 Across regions of Vietnam, the rate of return to schooling rises with mean schooling (Gallup, 2004).

13 This difference persisted; in 2004 the corresponding mean years of schooling were 8.0 and 4.8.
} 
There is likely to be heterogeneity in impacts within one area at a given time, which can also fuel debate. Consider the different views of Akram-Lodhi (2004, 2005) and the Center for Rural Progress (2004). Both draw (in part) on field work in the Mekong Delta, and at about the same time; yet they come to very different conclusions, one favoring PILE and the other not. This may partly reflect horizontal inequalities in economic and social change, whereby similar people ex ante fare differently; two researchers can then come back from field work at the same time in the same area with very different stories, depending on who they talk to. This speaks to the need for representative survey data when attempting to form generalizations.

Later we will see what light survey data can cast on these issues. However, the debate will not be resolved by data alone. There are also differences in the value judgments made. Some observers see rising land inequality as a bad thing per se, even if it comes with falling poverty. Here we will assume that, while inequalities in various dimensions may be instrumentally important to absolute levels of living, the latter are the overriding consideration.

Differences in the attribution of empirical observations to causes can also play a role. Suppose that a household suffers a serious health crisis, and has to sell its land. The household becomes both poor and landless. This would not have happened if there had been a ban on selling land. But the existence of a land market did not cause the poverty; indeed, the absence of a market could entail even greater poverty, by effectively de-valuing the household's main asset.

\section{Land markets, occupational choice and welfare}

The issues in this debate can be captured in a transparent way using a relatively simple model of how the occupational choices of poor farm-households are affected by a policy reform that removes restrictions on land markets. The model essentially pits the gains from expanded choice and specialization against the reform's "second-round" effects on other income sources, 
including through labor market responses. The balance of these opposing effects determines the reform's impacts. In drawing out the implications of our model we focus on three questions:

- Will landlessness rise among the poor as a result of this reform?

- Will the post-reform landlessness rate be highest for the poorest?

- Who will gain and who will lose?

\subsection{The model}

We focus on the impacts of allowing market-based land re-allocation. Thus we ignore forced landlessness, as can arise from compulsory acquisitions of farmland by the state, such as for public works or non-farm development projects. (Naturally such non-market sources of landlessness can generate welfare losses, depending on the terms of compensation.)

Wealth can be held as land, human capital or consumer durables. There is no credit market prior to the reform but, after the reform, liquidity-constrained borrowing is possible for those with land. The level of schooling is fixed post-reform and schooling can only be financed by disposing of marketable assets. ${ }^{14}$ Prior to the reform, land is equally allocated, giving $L_{0}=\bar{L}$, but cannot be traded or transferred. Pre-reform marketable assets, $A_{0} \geq A_{0}^{\min }$, can be devoted to schooling or consumer durables, "housing” $(H)$. Post-reform, the market value of assets rises to $A_{1}=A_{0}+\bar{L}$ (the price of land is set to unity). (A subscript “0" denotes pre-reform and "1" postreform.) With a market, land can be converted into housing subject to $A_{1}=H_{1}+L_{1} \cdot{ }^{15}$ Utility is $F+\phi(H)$ where $F$ is consumption of "food" and $\phi^{\prime}>0, \phi^{\prime \prime}<0 .{ }^{16}$ The optimal pre-reform levels

14 For evidence of a "wealth” effect on schooling in Vietnam see Glewwe and Jacoby (2004).

15 Note that selling land to improve housing (or buy other consumer durables) does not require that agricultural land be converted into residential land, which would require changes in land-use laws. 16 A more general model would allow leisure to have value and permit diminishing utility of food consumption; these features do not appear to be essential for our main results. 
of schooling and housing will be determined solely by $A_{0}$, and will be strictly increasing in $A_{0} \cdot{ }^{17}$

Thus we can treat $A_{0}$ as the indicator of schooling and pre-reform housing.

The household chooses between family farming and supplying $S$ of labor $(1 \geq S \geq 0)$ to an outside activity (commercial farming or producing consumer durables). There is a return to wealth in farming, as represented by (twice-differentiable) functions of non-land wealth, $g_{i}\left(A_{0}\right)$, $i=0,1$. Heterogeneity in ability at farming is represented by an i.i.d. random variable $\eta$. Own food output is $f\left(L_{i}\right)+g_{i}\left(A_{0}\right)+\eta(i=0,1)$, where the non-negative (twice-differentiable) function $f$ is taken to be non-decreasing and at least weakly concave. (Any income from renting-out land can be embedded in $f$.) Note that $f$ is taken to be unaffected by the reform. Alternatively one can allow for higher output from land due to greater security of land-use rights. ${ }^{18}$ While one could readily introduce this feature, we interpret this effect as being picked up by the $g_{i}$ functions.

The functions $g_{i}\left(A_{0}\right)$ can be interpreted in a number of ways: they can represent economic returns to schooling in farming, ${ }^{19}$ or costs of non-land inputs $\left(g_{i}\left(A_{0}\right)\right.$ can be negative for some $\left.A_{0}\right),{ }^{20}$ or some other contribution of wealth to output such as through local tax-transfers or (liquidity constrained) access to credit to finance non-land inputs to farming, which we assume is only possible once land can put up as collateral. We assume that the reform does not decrease farmers' marginal returns to non-land wealth. For the poorest, we also assume that the reform does not increase own food output at given land. More formally:

$17 \quad$ This follows from our assumption that utility is separable between food and consumer durables. 18 For supportive evidence see Deininger and Jin (2006) (using data for Ethiopia), who also refer to earlier literature, not all of which is supportive.

$19 \quad$ Van de Walle (2003) and Ngo (2004) provide evidence that schooling raises agricultural productivity in Vietnam. A more general model would allow for interaction effects with land holding. 20 At sufficiently high $A_{0}$ some farm-households in the model will employ (presumably un-skilled) wage labor in farming. Given our focus on the poor we do not model this explicitly, but we note some implications along the way. 
Assumption 1: $g_{i}^{\prime}\left(A_{0}\right) \geq 0, g_{i}^{\prime \prime}\left(A_{0}\right) \leq 0, g_{1}^{\prime}\left(A_{0}\right) \geq g_{0}^{\prime}\left(A_{0}\right)$ and $g_{1}\left(A_{0}^{\min }\right) \leq g_{0}\left(A_{0}^{\min }\right)$.

The assumption that $g_{1}\left(A_{0}^{\min }\right) \leq g_{0}\left(A_{0}^{\min }\right)$ is motivated by the policy debate summarized in section 2. Suppose that prior to the reform, the commune authorities in charge of land allocation provide certain benefits, such as help in acquiring complementary inputs to production or protection from idiosyncratic shocks. These benefits are curtailed once land markets are introduced, on the grounds that farmers can then be left to their own devises to obtain credit or to use land as a buffer against risk. Then we may find that $g_{1}\left(A_{0}\right)<g_{0}\left(A_{0}\right)$ at low $A_{0}$. Later we give an example of how this can happen.

The choice of $S$ and $L$ is constrained by the household's endowment of able-bodied labor and time (in short, its "labor constraint”). To simplify the analysis we assume that the labor constraint entails that the household specializes in either farming or wage labor in a non-farm activity, i.e., it chooses between $\{L>0, S=0\}$ and $\{L=0, S=1\} .{ }^{21}$ Food consumption is

$$
F_{i}=\left[f\left(L_{i}\right)+g_{i}\left(A_{0}\right)+\eta\right] I\left(L_{i}\right)+w_{i}\left(A_{0}\right) S_{i}\left[1-I\left(L_{i}\right)\right] \quad(i=0,1)
$$

where $w_{i}$ is the wage rate (which varies with $A_{0}$ through returns to schooling) and $I\left(L_{i}\right)$ takes the value 1 when $L>0$ and 0 when $L=0$.

The maximum pre-reform utility for a farmer is $f(\bar{L})+g_{0}\left(A_{0}\right)+\phi\left(A_{0}\right)+\eta$ and when landless it is $w_{i}+\phi\left(A_{i}\right)(i=0,1)$. The post-reform utility maximum in farming is $v\left(A_{0}\right)+\eta$ where:

$$
v\left(A_{0}\right) \equiv \max _{(L)} f(L)+g_{1}\left(A_{0}\right)+\phi\left(A_{0}+\bar{L}-L\right)
$$

21 If the household chooses landlessness then it will set $S=1$ given that we do not attach a value to leisure. If one introduced unemployment then $S$ will be set at the maximum available work. 
The optimal post-reform land-holding is $L_{1}^{*}=L\left(A_{0}\right)$. It is readily verified that $L^{\prime}\left(A_{0}\right)>0$. Farmers with $A_{0}>A^{*} \equiv L^{-1}(\bar{L})$ acquire more land when the market is introduced ( $L_{1}^{*}>\bar{L}$ ) while those with $A_{0}<A^{*}$ acquire less. We also impose an upper bound on the land demand of the poorest:

Assumption 2: $L\left(A_{0}^{\min }\right) \leq f^{-1}\left\{\phi\left(A_{0}^{\min }+\bar{L}\right)-\phi\left[A_{0}^{\min }+\bar{L}-L\left(A_{0}^{\min }\right)\right]\right\}$.

For example, this holds if $f\left[L\left(A_{0}^{\min }\right)\right]=0$, i.e., $L\left(A_{0}^{\min }\right)$ is too small a holding to be productive.

The probabilities of becoming landless ("landlessness rates”) are:

$$
\begin{aligned}
& L L_{1}=\Psi\left[w_{1}+\phi\left(A_{1}\right)-v\left(A_{0}\right)\right] \\
& L L_{0}=\Psi\left[w_{0}-f(\bar{L})-g_{0}\left(A_{0}\right)\right]
\end{aligned}
$$

Where $\Psi$ is the distribution function of $\eta$. Both $L L_{1}$ and $L L_{0}$ are strictly increasing in $w$ and non-increasing in $A_{0}$. Note that a landless class will emerge (with non-zero probability) postreform even if wealth is initially equal, given heterogeneous ability at farming.

The introduction of a land market can be expected to change labor-market outcomes. We assume competitive markets for labor of each skill/asset level, $A_{0}$. Labor supplies are given by (3.1) and (3.2). Demand is taken to be a stable non-increasing function of the wage rate and a non-decreasing function of $A_{0}$. Thus wage rates equate (3.1) and (3.2) with aggregate demands $D\left(w_{1}, A_{0}\right)$ and $D\left(w_{0}, A_{0}\right)$, giving wages $w_{1}=w_{1}\left(A_{0}\right)$ and $w_{0}=w_{0}\left(A_{0}\right)$, which are both nondecreasing functions. ${ }^{22}$ An alternative model would allow for unemployment, with the available work rationed according to wealth as the key determinant of productivity (as in an efficiencywage model). The following analysis allows either interpretation of $w_{i}\left(A_{0}\right)$.

22 Prior to the land market, the supply of labor is independent of $A$, but the wage rate will still be non-decreasing in $A$ via the demand side effect. 


\subsection{Implications for landlessness and poverty}

Intuitively, the asset rich will be able to acquire more land, giving larger output gains from their own farms. What about the asset poor? In this model there are two reasons why we can expect to find rising landlessness among the asset poor. The first is that the asset poor will have a higher marginal utility of housing, prompting them to sell their land and supply labor to other activities, driving down the unskilled wage rate. The second reason is that the asset poor may find that, after the introduction of a land market, they are less well insured against shocks and have lower access to non-land inputs to farm production; these effects arise though the induced responses of local authorities to the introduction of land markets.

To verify this intuition we can state and prove the following result:

Proposition 1: On introducing a land market, the landlessness rate will rise for the asset "poor" and fall for those who are sufficiently asset "rich."

To see why this holds, note first that, given stable downward-sloping demand functions, the equilibrium landlessness rate must be a decreasing function of the equilibrium wage rate i.e., the necessary and sufficient condition for $L L_{1}>L L_{0}$ (at given $A_{0}$ ) is that $w_{1}\left(A_{0}\right)<w_{0}\left(A_{0}\right)$. Thus a land market will increase landlessness if and only if $\mathrm{H}\left(A_{0}\right)<f(\bar{L})$ where: ${ }^{23}$

$$
\mathrm{H}\left(A_{0}\right) \equiv f\left[L\left(A_{0}\right)\right]+\phi\left[A_{0}+\bar{L}-L\left(A_{0}\right)\right]-\phi\left(A_{0}+\bar{L}\right)+g_{1}\left(A_{0}\right)-g_{0}\left(A_{0}\right)
$$

It is readily verified that $\mathrm{H}\left(A_{0}^{\min }\right) \leq 0$ under Assumptions 1 and 2 . So the reform must increase the landlessness rate for the asset poor. Differentiating (4) we also find that:

$$
\mathrm{H}^{\prime}\left(A_{0}\right)=\phi^{\prime}\left(A_{1}-L_{1}^{*}\right)-\phi^{\prime}\left(A_{1}\right)+g_{1}^{\prime}\left(A_{0}\right)-g_{0}^{\prime}\left(A_{0}\right)>0
$$

$23 \quad$ Note that (i) the labor-market clearing conditions can be written as $\Psi\left(w_{i}+x_{i}\right)=D\left(w_{i}\right)$ (for $i=0,1)$, implying that $w$ is a strictly decreasing function of $x$, the supply shift, and (ii) $\mathrm{H}\left(A_{0}\right)-f(\bar{L})$ indicates the shift in the labor supply functions at a given wage rate, as in (3.1) and (3.2).) 
(given that $\phi^{\prime \prime}<0$ ). Thus there will be a rise in the landlessness rate for all those with $A_{0}<\mathrm{H}^{-1}[f(\bar{L})]$ and a fall for $A_{0}>\mathrm{H}^{-1}[f(\bar{L})]$ (Figure 1). The switch point $\left(\mathrm{H}^{-1}[f(\bar{L})]\right)$ may be quite high; for example (as will be evident below) if $g_{1}\left(A_{0}\right)=g_{0}\left(A_{0}\right)$ then $\mathrm{H}^{-1}[f(\bar{L})]>A^{*}$, which is the asset level below which land is sold once the market is introduced.

It is clear from the above analysis that the reform's implications for the aggregate rate of landlessness — obtained by integrating (3.1) and (3.2) over the distribution of wealth — depend on the initial distribution of wealth; if more than (less than) half of the population have $A_{0}<\mathrm{H}^{-1}[f(\bar{L})]$ then the aggregate landless rate will rise (fall). Intuitively, the greater the initial asset poverty, the more likely aggregate landlessness will rise due to the reform.

Proposition 1 focused on the reform's impact on landlessness at given wealth. However, a rise in landlessness among the poor as a result of this reform does not imply that the poor are more likely to be landless than the rich after the reform; instead it may entail a flattening out of a positive wealth gradient in landlessness pre-reform. To assess to what extent class differentiation has emerged we must study the economic gradient in landlessness — whether it is the poor who tend to be landless, while the non-poor are not. We have:

Proposition 2: The post-reform wealth gradient in landlessness can go in either direction depending on the structure of returns to wealth.

On substituting $w_{1}=w_{1}\left(A_{0}\right)$ into (3.1), the wealth gradient is given by:

$$
d L L_{1} / d A_{0}=\psi(.)\left[w_{1}^{\prime}\left(A_{0}\right)+\phi^{\prime}\left(A_{1}\right)-\phi^{\prime}\left(A_{1}-L_{1}^{*}\right)-g_{1}^{\prime}\left(A_{0}\right)\right]
$$

( where $\psi()=.\Psi^{\prime}()>$.0 ). The gradient could be positive or negative (unlike the partial derivative at a given wage rate, which is negative). It is instructive to consider two stylized cases:

Case 1: Low labor-market returns to wealth. When the returns to schooling are low, farming will tend to be the more attractive option for the rich. Suppose that only unskilled labor 
is available and there are no other returns to wealth in farming, i.e., $w_{i}^{\prime}\left(A_{0}\right)=g_{i}^{\prime}\left(A_{0}\right)=0$. Without a land market, the landlessness rate does not vary with wealth. On introducing a market, it is evident from (6) that $L L$ is non-increasing in A, i.e., the landlessness rate tends to fall with higher wealth. Allowing for positive returns to wealth in farming $g_{i}^{\prime}\left(A_{0}\right)>0$ (such as through access to credit when land can be used as collateral), $L L$ will be decreasing in wealth both before and after the reform. In the special case of a uniform distribution of $\eta$ ( $\psi$ constant) and $g_{0}^{\prime}=g_{1}^{\prime}$ the wealth gradient will be everywhere steeper after the reform.

Case 2: High labor-market returns to wealth. Naturally, this makes the labor market more attractive to the rich. A positive wealth gradient in landlessness is found if the returns to schooling are sufficiently high, i.e., $w_{0}^{\prime}\left(A_{0}\right)>g_{0}^{\prime}\left(A_{0}\right)$ and $w_{1}^{\prime}\left(A_{0}\right)>g_{1}^{\prime}\left(A_{0}\right)+\phi^{\prime}\left(A_{1}-L_{1}^{*}\right)-\phi^{\prime}\left(A_{1}\right)$. With a uniform distribution of $\eta$ and a structure of returns to wealth that is unaffected by the reform, the wealth gradient will be everywhere flatter after the reform.

Alternatively, we can characterize the different outcomes in terms of the wealth gradient in non-land inputs $\left(g_{i}^{\prime}\left(A_{0}\right)\right)$. Plainly, a sufficiently positive (negative) gradient in command over non-land inputs will tend to yield a negative (positive) gradient in the landlessness rate.

Turning finally to the incidence of the reform's welfare impacts, we have:

Proposition 3: There can be both gainers and losers from this reform, implying that the impact on aggregate poverty is ambiguous.

Let us begin with the case of a farmer who stays a farmer. A welfare gain requires that:

$$
\Gamma\left(A_{0}\right) \equiv f\left(L_{1}^{*}\right)+\phi\left(A_{0}+\bar{L}-L_{1}^{*}\right)-\phi\left(A_{0}\right)+g_{1}\left(A_{0}\right)-g_{0}\left(A_{0}\right)>f(\bar{L})
$$

We find that (using the envelope theorem):

$$
\Gamma^{\prime}\left(A_{0}\right)=\phi^{\prime}\left(A_{0}+\bar{L}-L_{1}^{*}\right)-\phi^{\prime}\left(A_{0}\right)+g_{1}^{\prime}\left(A_{0}\right)-g_{0}^{\prime}\left(A_{0}\right)
$$


Consider first the special case in which $g_{1}\left(A_{0}\right)=g_{0}\left(A_{0}\right)$. Note that $\Gamma^{\prime}\left(A_{0}\right)>(<) 0$ as $L_{1}^{*}>(<) \bar{L}$, i.e., as $A_{0}>(<) A^{*}$. Thus $\Gamma\left(A_{0}\right)$ has a U-shape, with a minimum at $A^{*}$, where $\Gamma\left(A_{0}\right)=f(\bar{L})$ and $\Gamma\left(A_{0}\right) \geq f(\bar{L})$, as in Figure $1 .^{24}$ There is a welfare gain (or at least no loss) for all farmers.

Clearly this result also holds if $g_{1}\left(A_{0}\right)>g_{0}\left(A_{0}\right)$ for all $A_{0} \cdot{ }^{25}$ However, farmers with $g_{1}\left(A_{0}\right)<g_{0}\left(A_{0}\right)$ could be worse off due to the reform. To give a concrete example, suppose that $g_{i}\left(A_{0}\right)$ is the extra farm output that can be obtained with access to credit for acquiring non-land inputs, given $A_{0}$. Prior to the land-market reform, the same local authorities who allocate the land equally by administrative means also give everyone equal access to credit, i.e., $g_{0}\left(A_{0}\right)=\bar{g}_{0}$. After the reform, farmers turn to an (imperfect) credit market in which lenders only provide credit on terms that assure the farmer wants to stay a farmer. (We assume that this constraint holds in expectation only, in that the latent ability variable $\eta$ is set to its mean of zero.) Then $g_{1}\left(A_{0}\right)$ equates $v\left(A_{0}\right)$ with utility when landless, giving:

$$
g_{1}\left(A_{0}\right)=w_{1}\left(A_{0}\right)+\phi\left(A_{0}+\bar{L}\right)-\phi\left(A_{0}+\bar{L}-L_{1}^{*}\right)-f\left(L_{1}^{*}\right)
$$

Now we find that a farmer gains (loses) from the reform according to whether $w_{1}\left(A_{0}\right)+\phi\left(A_{0}+\bar{L}\right)-\phi\left(A_{0}\right)$ is greater then (less than) $f(\bar{L})+\bar{g}_{0}$. The "asset poor" will lose if the unskilled wage rate is sufficiently low $\left(w_{1}\left(A_{0}^{\min }\right)<\bar{g}_{0}+f(\bar{L})+\phi\left(A_{0}^{\min }\right)-\phi\left(A_{0}^{\min }+\bar{L}\right)\right)$, since they can attract little credit to finance non-land inputs to farm production. A clear separation into “asset-poor losers" and "asset-rich gainers" is also possible if the returns to schooling in the labor market are sufficiently high $\left(w_{1}^{\prime}\left(A_{0}\right)>\phi^{\prime}\left(A_{0}\right)-\phi^{\prime}\left(A_{0}+\bar{L}\right)(>0)\right)$.

$24 \quad$ Note also that $\Gamma\left(A_{0}\right) \geq \mathrm{H}\left(A_{0}\right)$ (given that $\Gamma\left(A_{0}\right)=\mathrm{H}\left(A_{0}\right)+\phi\left(A_{1}\right)-\phi\left(A_{0}\right)$ ). It follows that $\mathrm{H}^{-1}[f(\bar{L})]>A^{*}$ when $g_{1}\left(A_{0}\right)=g_{0}\left(A_{0}\right)$, as claimed in the example following Proposition 1 (Figure 1 ). $25 \quad$ Introducing labor hiring by farmers with sufficiently large holdings would add further welfare gains to better-off farmers due to the reform's impact on the unskilled wage rate. 
Now consider a farmer who becomes landless as a result of the reform. Clearly she cannot be worse off after the reform than if she had stayed a farmer. Having established above that no farmer loses as a result of the reform for the case in which $g_{1}\left(A_{0}\right) \geq g_{0}\left(A_{0}\right)$, it cannot be the case that those farmers who choose to become landless lose as a result of the reform. However, when $g_{1}\left(A_{0}\right)<g_{0}\left(A_{0}\right)$ there can be losers among the newly landless.

Lastly, consider the pre-reform landless who stay landless. All that matters to the welfare impact for this group is what happens to the wage rate. For this group, a rise in landlessness signals a welfare loss, through the impact on the wage rate. Thus we have verified Proposition 3.

In the above analysis, welfare losses from a land market arise from labor market effects or diminished command over non-land inputs to production. Losses can also occur with lags in labor-market adjustment and distortions in land markets. Suppose that the decision to sell one's land is made before the new labor market equilibrium is revealed and that there is a sufficiently large transaction cost to prohibit buying-back land; this can arise if the value of the land to the new owner exceeds the prior purchase price, as would be the case when the land purchases allow the consolidation of previously fragmented plots. With a fall in the wage rate due to the reform, some farmers who sell their land will find that they are worse off in equilibrium.

\section{Data and summary statistics}

We use the unit-record data from four nationally-representative surveys by the General Statistical Office, for 1993, 1998, 2002 and 2004 with sample sizes for rural areas are 3,800, 4,300, 22,600 and 6,900 for 1993, 1998, 2002 and 2004 respectively. All four surveys are representative for the seven regions that Vietnam is commonly divided into. The 1993 sample is self weighted, while the other surveys used stratified random cluster sampling so that sampling weights need to be applied. The first survey was done just before the 1993 Land Law. 
We do not have panel data spanning 1993-2004. ${ }^{26}$ Thus we cannot measure welfare changes over time for those who were farmers in 1993 but landless in 2004. Nor can we trace farmers who became landless and moved to urban areas (which is also impossible with most panels). Observed changes over time will reflect (in part) the changing internal composition of given socio-economic groups. For example, if relatively worse-off farmers sell their land this will put upward pressure on the poverty rate among the landless. Comparing a poverty measure for the landless over time, we cannot say how much is due to changing living conditions among the initially landless versus low living standards among those who become landless.

We do not have data on wealth, and we use consumption expenditure instead (the same consumption measure used in measuring poverty and inequality). We use a measure of household consumption per capita that is comparable across the four surveys, is expressed in real January 1998 prices and is appropriately deflated for spatial and monthly price variation. ${ }^{27}$ Consumption includes the imputed rental value of housing and the use value of durable goods (see World Bank 1995, 2000; Glewwe, 2003, 2005). Figure 2 gives the frequency distribution of log consumption per person for 1993 and 2004 (these will help interpret later results); the upper panel is for rural Vietnam as a whole. (The lower panel is for the landless, which we return to.)

We have no choice but to use current consumption, which will reflect impacts of the land reforms after 1993. (Ideally we would have pre-intervention consumption but this would require panel data.) We will comment on likely biases arising from this feature of the data.

The land concept we use is the amount of "cultivated land" in the annual, perennial, water-surface and forest categories. We define a household as landless if it has no land other

26 The first two surveys contain a subset of the sample that form a panel, as do the 2002 and 2004 surveys; but there is no panel link between the 1998 and 2002 surveys. There is also likely to be selective attrition in the two panels, in particular by those who sold/lost their land.

$27 \quad$ In designing the 2002 and 2004 surveys, considerable effort was made to ensure that household consumption could be measured in a comparable way to previous surveys. 
than land it rents in or residential or swidden land. ${ }^{28}$ We make a distinction between "landless" and "non-cultivating" households; the latter include those who rent out all their land. ${ }^{29}$

The unemployment rate among the landless is low. Based on adults who report that they did not work because they could not find work in the last 12 months, only $2.6 \%$ of landless rural households in 2004 had an unemployed adult, and this was almost identical in 1993 (2.5\%). ${ }^{30}$

The rate was lower in the MD $(2.1 \%$ in $2004 ; 1.6 \%$ in 1993). However, time-use data might well reveal higher rates on underemployment, depending on the season.

Table 1 provides summary statistics. For rural Vietnam, the landlessness rate increased by two-thirds over the period, to slightly more than $12 \%$ in 2004 . (These are population weighted; the proportion of households who were landless rose from $8.4 \%$ to $13.6 \%$.) The rise in landlessness naturally put upward pressure on the inequality of land holdings. ${ }^{31}$ In all years, the poverty rate is higher for those with land than for the landless. Similarly, mean consumption is higher for the landless. There was a sharp contraction in the incidence of poverty, which occurred at roughly the same rate for those with land as the landless. Over 1993-2004, the proportionate gain in consumption was higher for those with land; the ratio of the mean consumption for the landless relative to those with land fell between 1993 and 2004 from 1.33 to 1.24, though within the period it fell (to 1.21 in 1998) then rose (back to 1.33 in 2002).

$28 \quad$ We tested two alternative definitions, one that excludes auction land and one that additionally excludes land contracted from state farms. The second gives a slightly higher landlessness rate (14.5\% of households) in 2004 but as it can only be calculated for 1998 and 2004 we stick with the first definition. 29 The surveys have different land modules, although comparisons are still feasible. A limitation of the 2002 survey is that it only gives the amount of land that is cultivated by households, whether they have long term use rights to the land or are renting it in. While we know if the household rents-out land, we cannot identify how much and, hence, the total amount over which the household has use rights. $30 \quad$ For 1993 one can also calculate an unemployment rate for whether work was wanted but could not be found in the last 7 days; this gives an even lower rate for rural areas of $0.5 \%$ (Gallup, 2004). 31 We found that the 2004 Lorenz curve was nowhere above that for 1993 for either annual crop land or perennial land. 
Table 1 also gives an inequality measure, the mean log deviation (MLD), defined as the $\log$ of mean consumption minus the mean of log consumption. ${ }^{32}$ We find that inequality is higher among the landless than those with land, but there is a sign of convergence, with increasing inequality among those with land and decreasing inequality among the landless.

The lower panel of Figure 2 shows how the distribution of consumption changed for the landless. The rise in the mean and fall in poverty is evident. But there is no sign of marked polarization among the landless. We are not seeing the emergence of two clear sub-groups among the landless, one poor and one not.

The patterns for rural Vietnam also hold for the majority ethnic group in all four years (Table 2) ${ }^{33}$ For the minority groups — who are appreciably poorer on average and less likely to be landless — the poverty rate was higher for landless households in the 1990s, but this switched in 2002 and 2004 to the same pattern found for the majority. The (absolute and proportionate) rate of decline in poverty is greater among the landless minorities than for those with land.

Table 2 gives a regional breakdown. The landlessness rate is higher in the south, notably in South-East (SE) and the MD and the landless tend to be less poor in all regions except the MD. There was a decline in poverty incidence among the landless in all regions, though the rate of poverty reduction for the MD's landless is lower than for those with land; in 1993, the landless in the MD were about 20\% more likely to be poor than those with land; by 2004 the landless were twice as likely to be poor. There is little sign of polarization in the consumption distribution among the MD landless; similarly to Figure 2(b), the frequency distribution of consumption in the MD was no more bi-modal in 2004 than in 1993. Nor did we find any sign

32 This is the E(0) measure in the Generalized Entropy class. The measure has a number of desirable properties including exact additive decomposability by sub-groups, which we exploit later.

33 Although the Chinese represent a tiny minority, they tend to be well-off and more similar to the Kinh majority than to other minority groups. For this reason we include them in with the majority group. 
that other regions are following in the footsteps of the MD; elsewhere, the rate of poverty reduction among the landless has kept pace (or even exceeded) that for the landed.

\section{Incidence and sources of rising landlessness}

As we saw in section 2, there have been two very different interpretations of rising landlessness in the wake of Vietnam's land market reforms. The first says that, starting from a relatively equitable allocation of land, a rural class structure emerged as rich farmers bought land from poor farmers, who then became the poor landless laborers found at the bottom of the new class structure. By this view, the main dynamic in the transition process that has led to rising landlessness is a structural shift in the relationship between landlessness and living standards, whereby, in the wake of the reforms, the probability of being landless rises among the poor.

The second interpretation assumes that rising living standards in a developing economy inevitably entail a partial shift out of farming. With sufficiently high returns to schooling it is more likely to be the non-poor who tend to be landless. By this view, there need not be any change over time in the relationship between the probability of being landless and one's standard of living. Rather, both rising landlessness and falling poverty happen in tandem, as some farmers choose to sell their land to take up new opportunities. Instead of a "structural" shift in the relationship between landlessness and poverty, rising landlessness and falling poverty jointly reflect a process of economic transition made possible by the introduction of land markets.

The rest of this paper tries to see which of these interpretations is more consistent with the data. In this section we focus on the changing incidence of landlessness across levels of living and the role this has played in the rise in aggregate landlessness. Section 6 examines the incidence of wage labor and credit utilization, both of which are expected to change after freeing 
up land markets. Then section 7 turns to the relationship between the geographic pattern of landlessness and poverty measures.

\subsection{Incidence of rising landlessness and land transactions}

Figure 3 gives the relationship between the mean landlessness rate and log consumption per person (in 1998 prices) for 1993 and 2004. (These are non-parametric regressions, using locally-smoothed scatter plots.) Rural landlessness in 2004 tends to have a positive consumption gradient; the poorest tend to be the least likely to be landless. In terms of our theoretical analysis in section 3, this pattern is consistent with sufficiently high labor-market returns to schooling or other assets. ${ }^{34}$ Note also that the landlessness rate for 2004 is nearly linear in log consumption, implying that it is concave in the level of consumption; thus higher (lower) consumption inequality at a given mean will tend to lower (raise) the aggregate landlessness rate.

How will the fact that we are using 2004 consumption (which reflects gains from the reform as well as other changes since 1993) affect the estimated relationship with landlessness in 2004? This will depend on how the consumption gains since 1993 vary with landlessness. If the (proportionate) gains tend to be higher (lower) for those who become landless and landlessness rises with consumption then we will over-estimate (underestimate) the true economic gradient in landlessness. The fact that the proportionate gain in consumption over 1993-2004 was slightly lower for those with land suggests that we will be underestimating the economic gradient in landlessness measured against pre-reform consumption.

Over the period 1993-2004, there was a reduction in landlessness among the poorest (Figure 3), though less than 3\% of households in 2004 had consumption per person below the

$34 \quad$ It is not clear that returns to schooling need to be high for a positive gradient in landlessness. In common with China (Fleisher and Wang, 2004), wage compression in the more organized labor markets has kept returns to schooling relatively low in Vietnam; see Gallup (2004) and Nguyen (2004b) for the 1990s, although it appears that returns to education have increased substantially in recent years (World Bank, 2005, Chapter 7). Note also that the gradient could reflect a wealth effect on non-farm earnings. 
lower intersection point in the regressions. Note also that, although we see only a relatively small interval of consumption for which there is rising landlessness, it is clear from Figure 2 that there is a large share of the data in this interval. In 1993, about $69 \%$ of the population lived in households with consumption per person in the interval for which landlessness rose; in 2004 the proportion fell to $42 \%$. Thus, a large share of the population had consumption in the interval for which there was a rise in the mean landlessness rate conditional on consumption.

Note that there are landless households who still cultivate land by renting it in, and there are households who are not landless by our definition but do not cultivate — by renting out land. Figure 4 shows how the share of non-cultivating households varies with log consumption for 1993 (panel a) and 2004 (b). We find a marked change in rental behavior as a function of living standards. In 1993, the poorest rented in land on average, so the non-cultivating rate was lower than the landlessness rate; at higher consumption levels, the two were roughly equal. This had changed by 2004, with the non-poor renting out land, so the economic gradient of the share of non-cultivating households was even steeper than that of landlessness (Figure 4b).

The ethnic minorities do not accord well with the predictions of our theoretical model. Landlessness is found to have fallen for poor rural minority households, and risen for higher consumption groups (Figure 5). The choices of the minorities may well be constrained by discriminatory features of labor markets that are not incorporated in our model; arguably land markets also work differently, given that the minorities tend to be concentrated in mountainous areas. ${ }^{35}$ Among minorities, the overall correlation between landlessness and (log) consumption per person switches sign over the period, from being negative but not significant $(r=-0.04)$ in

35 On the sources of inequality between the minority and majority ethnic groups in Vietnam see van de Walle and Gunewardena (2001), whose results offer some support for our interpretation. 
1993 to positive and significant ( $\mathrm{r}=0.09$ ) in 2004. Thus it looks like the relationship for the minorities has become more like that for the majority.

We find rising landlessness among the poor in the fertile northern and southern deltas (Figure 6). Recall that the landlessness rate is much higher in the MD; 23\% in 2004 versus 6\% in the RRD (Table 2). The contrast is striking. In the RRD, landlessness rises with consumption while it is roughly the reverse in the MD. ${ }^{36}$ The RRD is consistent with Case 2 in section 3 in which returns to schooling are relatively high, while the pattern for the MD is more consistent with Case 1, in which returns to schooling are relatively low; these differences in the labormarket returns to schooling accord with the evidence cited in section 2. The historical differences noted in section 2 also make it more likely that access to non-land inputs was more wealth-dependent in the MD, creating pressure toward a negative wealth gradient in landlessness. Over time we find rising landlessness among the poor in both regions, as predicted by our theoretical model. In the MD we also find a marked rise in landlessness among the highest consumption households, as well as for the bulk of the poor. Comparing Figures 6(a) and 6(b), it is evident that the big difference is in the incidence of landlessness among the poor. Among the poorest (log consumption around 7) the landlessness rate is about 5\% in RRD versus $40 \%$ in MD.

Before exploring the sources of rising landlessness more closely, it is worth noting that there were also changes in the relationship between the size of land-holding and levels of living among those with land. Figure 7 plots (log) land holding (all types) against (log) consumption. We see that land holding conditional on consumption became more equal; the sharp positive

36 Recall that there will be a bias in using these regressions to infer the relationship with pre-reform consumption due to the fact that we are using post-reform consumption for 2004. Unlike for Vietnam as a whole (Figure 3) when the true relationship is negative (as for MD) the sign of this bias is indeterminate. 
gradient found in 1993 had largely vanished by 2004. Simultaneously with rising landlessness, the distribution of land holdings became more equal across levels of living. ${ }^{37}$

Figure 7 is not consistent with our model's prediction that post-reform landholding should have a positive wealth gradient. However, our model ignored heterogeneity in land quality. On a closer inspection we find that the poor have not seen gains in their land quality. This is evident from Figure 8, which gives the share of annual crop land that is irrigated. We see marked gains over time at all levels except among the poorest. The same pattern was also found when we looked at the distribution of the share of annual crop land that the commune authorities rated as high quality (details available from the authors). A plausible explanation for these differences is the initial inequality in non-land wealth, given credit market failures. Those with wealth were naturally in a better position to invest in their land. ${ }^{38}$

The 2004 survey allows us to study how land was acquired. ${ }^{39}$ Figure 9 shows how the incidence of land transactions varies with consumption. The totals include all means of acquiring or disposing of land that are allowed under the land laws (purchase, sale, inheritance, bequest, exchange). We also identify purchase and sale. We see that the upper consumption groups were more likely to take up the new opportunities for land-market transactions. These data are clearly not consistent with the view that the poor were selling their land to the rich and remaining poor. (It is likely that some of the transactions observed at middle consumption levels are for those who were previously poor.) This is further supported by Figure 10, which shows how each household's land-holdings in 2004 were initially acquired. We see that the poor in 2004 had relied heavily on reclaiming land, and hardly at all on market transactions for obtaining land; the purchase of land was more likely for the rich.

$37 \quad$ The changes in the distribution of annual land show a very similar pattern.

38 This echoes Taylor's (2004) observations from field work in the Mekong Delta.

39 The relevant questions were not asked in prior surveys. 
Land titling, in the form of land-use certificates (LUCs), was an important element of the 1993 land law. Figure 11 gives the proportion of land with a LUC. ${ }^{40}$ We see that LUCs are less common among the poor. Again we see that it is the relatively well-off within rural society who appear to be benefiting from the new land market.

\subsection{Decomposition of the change in landlessness}

The aggregate landlessness rate is obtained by integrating the conditional landlessness rate across the distribution of consumption. The overall rise in landlessness in rural areas thus reflects both a shift in the relationship between land holding and consumption — the economic gradient in landlessness studied in section 3 - as well as a shift in the distribution of consumption. This can be seen if we divide the population into $m$ consumption groups and decompose the change in the proportion of landless between 1993 and 2004 as follows:

$$
L L_{04}-L L_{93}=\sum_{i=1}^{m}\left(L L_{04 i}-L L_{93 i}\right) n_{93 i}+\sum_{i=1}^{m} L L_{04 i}\left(n_{04 i}-n_{93 i}\right)
$$

Here $L L_{t i}$ is the landlessness rate for consumption group $i=1, . ., m$ at date $t$ while $n_{t i}$ is the proportion of households in group $i$ at date $t$. The first term on the RHS gives the contribution of the change in the relationship between landlessness and consumption — the "land reallocation" component — while the second term gives the contribution of changes in the distribution of consumption — the "consumption redistribution" component.

Table 3 gives the decompositions, based on fractiles of 1993 consumption per person. ${ }^{41}$ We find that the change in the relationship between landlessness and consumption increased the overall landlessness rate by $2.3 \%$ points, while the change in the distribution of consumption

\footnotetext{
40 To derive the share of land with a LUC we aggregated plot-specific responses, weighted by plot sizes.

$41 \quad$ Given the large shift to the right in the distribution of consumption we had to choose fractiles carefully, to avoid small sample size. The precise fractiles by region are given in the Appendix.
} 
increased the landlessness rate by $2.9 \%$ points, giving a total of $5.1 \%$. Slightly more than half of the increase in landlessness is directly associated with falling poverty, as rural households who moved out of poverty also moved out of farming.

In the south, by contrast, the rise in landlessness was due to a land re-allocation effect (Table 3). This shift in the structural relationship between landlessness and living standards does not, however, accord well with the class-differentiation view. Figure 6(b) suggests that the shift in the relationship between landlessness and living standards in the MD combined two factors: a vertical rise in landlessness at all levels of consumption and a horizontal shift, with rising consumption. (The SE showed a similar pattern.) The land-reallocation effect in the south can be interpreted as the combined effect of higher landlessness with rising living standards.

\section{Incidence of wage labor and formal credit}

The introduction of land markets is expected to bring changes in two other markets, namely for wage labor and credit. We briefly examine both.

\subsection{Wage employment}

We find a striking change in the economic gradient of wage labor (Figure 12). In 1993 there was no (monotonic) relationship between the number of adults (17 and over) working for a wage and household consumption; the poor were just as likely to do wage work as the rich. This changed in 2004, with a strong positive relationship emerging; the poorest were working less for wages in 2004, but were working more in farming than in 1993. However, only $1.2 \%$ of households in 2004 have consumption less than the intersection point in Figure 12; for the bulk of the 2004 population there is a marked increase in wage labor supply at given consumption. 
There is a notable difference between the RRD and the MD in the incidence of wage workers, as is evident in Figure $13 .{ }^{42}$ In the RRD, wage work has a positive economic gradient similar to the country as a whole in 2004 (but not 1993). However, the direction of the relationship reverses in the MD, with wage work more common among the poor. In the MD, the rise in landlessness entailed a shift into wage labor.

\subsection{Credit}

One of the expected gains from liberalizing land markets is to enhance access to formal credit. We see signs of this in Figure 14, panel (a), which gives the regression of the share of households who reported that they borrowed money from a formal credit source in the last 12 months against consumption for both 2004 and 1993; panel (b) gives the corresponding regressions for the landless. (Formal credit is defined as credit from Banks and various organizations, as distinct from "informal credit” from individuals. ${ }^{43}$ )

However, while the landed were more likely to use formal credit in both years than the landless, both groups experienced rising credit utilization over time; in 1993 the mean proportion using formal credit was $21.68 \%$ for farmers $(\mathrm{n}=3514)$ and $11.15 \%$ for the landless $(\mathrm{n}=323)$, while in 2004 the corresponding proportions were $35.58 \%(\mathrm{n}=6035)$ and $23.34 \%(\mathrm{n}=904)$. We also see a strong economic gradient in the expansion in formal credit for both landed and landless (Figure 14); there was no gain for the poorest among the landless. There are also signs in these data that formal credit displaced informal credit. The corresponding graphs for

\footnotetext{
42 The corresponding graphs for self-employment in farming were similar between the two regions, and similar to the national pattern.

43 The sources of formal credit have increased over the period, as providing credit became a policy goal. In 1993, formal credit sources include private bank; other government bank; cooperative; and other. In 2004, they include social policy bank, agricultural and rural development bank, other banks, the fund for employment promotion, credit organizations and political/social organizations. Informal credit sources comprise private money lenders, relatives, and other individuals in 1993 and individual lenders, friends/relatives and other sources in 2004.
} 
utilization of informal credit sources show a negative economic gradient with lower overall utilization in 2004 than $1993 .{ }^{44}$ The main change was a displacement of informal credit by formal credit (for both landed and landless) rather than an overall increase in credit utilization.

It is not surprising that the landless are less likely to get formal credit at given consumption, since they lack the collateral provided by land. But it is worth noting that the landless poor are also less likely to receive credit from the national anti-poverty program. ${ }^{45}$ The 2004 survey asked whether respondents had participated in the anti-poverty programs (since 1999). Figure 15(a) gives the conditional probabilities of receiving subsidized credit through these programs for both farmers and the landless. We see that among the poor, the landless are appreciably less likely to receive credit from this source, which appears to be targeted instead to poor farmers. Possibly the lack of land is seen to make the landless a credit risk. However, the bias appears to go deeper than this, since we find a similar pattern in participation in the noncredit components of the anti-poverty programs, as can be seen in Figure 15(b). The sources of this evident bias against the landless poor merit attention in future research.

\section{Poverty-increasing landlessness?}

There are a number of further observations that lead us to question the idea that rising landlessness has increased poverty, as a generalization of Vietnam's experience over this period. We focus on the relationship between rates of poverty reduction across regions and the increases in landlessness. Clearly this relationship does not solely reflect the reforms; for example, the

44 Details are available from the authors. The mean proportion using informal credit in 1993 was $39.21 \%$ for farmers and $40.87 \%$ for the landless, while in 2004 the proportions were $20.36 \%$ and $21.13 \%$ $(\mathrm{n}=904)$.

$45 \quad$ Credit subsidies are targeted to Vietnam's poor through the Hunger Eradication and Poverty Reduction Program and Program 135. These programs also provide help with health care costs and local infrastructure, though micro credit is the main instrument. 
changes in the south may reflect a continuing process of land consolidation through quasi-market processes that predate the reforms.

One test of PILE takes the form of a "proof by contradiction": we show that, under certain assumptions, PILE implies things that we do not find in the data. To see why, consider a stylized version of PILE according to which initially non-poor farmers become poor after abandoning their land. This would clearly put upward pressure on the poverty rate among both the landless and those with land. For rural Vietnam, the impact on the poverty rate among the landless will exceed that for the group with land. This is readily verified if we note that moving one non-poor household out of the group of farmers will increase the poverty rate by $d H^{L>0}=H^{L>0} / N^{L>0}$ (where $H^{L>0}$ and $N^{L>0}$ denote the headcount index for those with land and the number of such respectively) while adding one poor household to the group of landless will increase the poverty rate in that group by $d H^{L=0}=\left(1-H^{L=0}\right) / N^{L=0}$ (in obvious notation) We find that $\left(1-H^{L=0}\right) / H^{L=0}>N^{L=0} / N^{L>0}$ in all years, using the estimates from rural Vietnam from Table 1, implying that $d H^{L=0} / H^{L=0}>d H^{L>0} / H^{L>0}$. The proportionate increase in the poverty rate will be higher for the landless. On top of this effect of rising landlessness, we can allow for an independent trend due to other factors. For lack of a more plausible assumption, we assume that the proportionate rate of poverty reduction due to other factors is the same between the two groups. Under PILE, we would then expect that poverty will fall less rapidly among the landless, given that rising landlessness will put a break on their rate of poverty reduction. That implication is not borne out by the data for Vietnam as a whole; indeed, the trend rate of poverty reduction between 1993 and 2004 is slightly higher for the landless (Table 1). However, while this version of PILE does not offer a convincing explanation of these data, the above test cannot reject PILE for the MD, where the rate of decline in poverty is lower for the landless. 
There are other aspects of the data that cast further doubt on PILE, at least for Vietnam as a whole. We have seen that for rural Vietnam as a whole, living standards tend to be higher for the landless. Suppose that a change in the share of the rural population that is landless comes about without any change in the distributions of consumption within each of the two groups. In other words, a representative household among farmers is transformed into a representative household among the landless. Rising landlessness must then cause a fall in the poverty rate. To see why, note that $H=H^{L>0}+\left(H^{L=0}-H^{L>0}\right) L L$ where (as before) $L L$ is the proportion who are landless. Then, under the within-group neutrality assumption, $\partial H / \partial L L=H^{L=0}-H^{L>0}$. This is negative for rural Vietnam in all years (Table 1) but (again) the MD is an exception; rising landlessness holding within-group distribution constant will be poverty-increasing in the MD.

We can use a difference-in-difference model to relax the within-group neutrality assumption in the above test. While the absence of household panel data spanning the period precludes use of a household fixed-effects specification, we can construct a geographic panel (within the limits of the sample sizes). In particular, we regress the log headcount index for each of the two groups (those with land and those without) for region $i$ at date $t$, on the landlessness rate allowing for regional and time effects:

$$
\ln H_{i t}^{L>0}=\alpha+\beta L L_{i t}+\pi_{i}+\delta_{t}+\varepsilon_{i t}(i=1, . ., N ; t=1, \ldots, T)
$$

where $\pi_{i}$ is a regional effect, $\delta_{t}$ is a time effect (such as due to macroeconomic or national agroclimatic conditions) and $\varepsilon_{i t}$ is a white-noise error term. We estimate a similar regression for the landless, with dependent variable: $\ln H_{i t}^{L=0} .^{46}$

\footnotetext{
46 We estimated this model using both the linear headcount index and its log, though the log specification gave a better fit for those with land.
} 
This specification allows landlessness to be endogenous as long as this is solely through the fixed effects, i.e., $\operatorname{Cov}\left(L L_{i t}, \pi_{i}\right)=\operatorname{Cov}\left(L L_{i t}, \delta_{t}\right) \neq 0$ but $\operatorname{Cov}\left(L L_{i t}, \varepsilon_{i t}\right)=0$. Then OLS estimates of the impact parameter $\beta$ tell us the average causal impact of higher landlessness; under PILE we will find that $\beta>0$. However, the assumption that $\operatorname{Cov}\left(L L_{i t}, \varepsilon_{i t}\right)=0$ can be questioned. The changes over time in the landlessness rate may be correlated with changes in other factors influencing poverty. The direction of bias in $\hat{\beta}$ could go either way. For example, unusually good (regionally and temporally specific) agro-climatic conditions may simultaneously reduce poverty and encourage farmers to stay on the land; then $\operatorname{Cov}\left(L L_{i t}, \varepsilon_{i t}\right)>0$, implying that our estimate will be biased in favor of PILE, underestimating the poverty-reducing impact of landlessness. Region and year-specific shocks to non-farm output yield the opposite bias. We would conjecture that in a poor rural economy the bias arising from shocks to agriculture will be dominant, implying that the rise in landlessness is more pro-poor than our DD test suggests. Pooling regions and dates from Table 2 (N.T=28), for the group with land we obtained $\hat{\beta}=-0.034$ with a t-ratio of-2.848 (based on a White standard error). The statistical precision improved when we dropped two regional effects that had very low t-ratios (North-Coast and MD); then we obtained $\hat{\beta}=-0.037$ with $\mathrm{t}=-6.547$. This suggests that rising landlessness has been poverty reducing among those with land and the effect is statistically significant. There is a poverty increasing effect among the landless, but it is not statistically significant; the corresponding regression for the landless gave $\hat{\beta}=0.020$ with $\mathrm{t}=0.561$.

These empirical findings point to a distributional non-neutrality in the impacts of rising landlessness, whereby it tends to be poor farmers who become landless, echoing our theoretical 
model in section $3{ }^{47}$ Thus higher landlessness comes with a lower poverty rate among those with land, but we do not find a statistically significant impact on the poverty rate among the landless. This suggests that there are both gainers and losers in this group.

Although not strictly consistent with the above tests, it is of interest to see what happens if instead we use the aggregate poverty rate (across both landless and those with land) as the dependent variable. This gives a simple DD test of PILE. With this change, we obtain $\hat{\beta}=-0.042$ (t-ratio $=-10.187){ }^{48}$ Rising landlessness has been poverty reducing overall and the effect is statistically significant.

To assess the size of this effect, note that the $\log$ of the national $H$ fell by 1.008 between 1993 and 2004. Our latter estimate of $\beta$ thus implies a change in $\ln H$ of -0.189 that is attributable to the fact that the landlessness rate rose by $4.5 \%$ points over this same period. Thus our estimate of the impact on the aggregate poverty rate implies that $19 \%$ of the total reduction in rural poverty is attributable to rising landlessness.

The poverty-reducing effect of rising landlessness is in part distributional. This can be seen if we add (log) mean consumption to the regression — to purge the poverty measure of the effect of differences in mean consumption, leaving the distributional effect. We obtained: ${ }^{49}$

$$
\ln H_{i t}=\underset{(16.45)}{17.944}-\underset{(-12.78)}{1.840} \ln M_{i t}-\underset{(-2.81)}{0.016} L L_{i t}+\hat{\eta}_{i}+\hat{\delta}_{t}+\hat{\varepsilon}_{i t} \quad R^{2}=0.973 ; n=28
$$

About $60 \%$ of the landlessness effect is transmitted through mean consumption, leaving $40 \%$ transmitted through more pro-poor distribution.

$47 \quad$ This is confirmed by regressing the inequality index among those with land on $L L$ (allowing for regional and year effects); we find a regression coefficient of -0.0016 , which is significantly different from zero at the $5 \%$ level ( $\mathrm{t}=-2.14)$; there is no such effect on inequality among the landless.

$48 \quad$ We dropped highly insignificant regions; with a complete set of regional effects we obtained $\hat{\beta}=-0.032$ with a t-ratio of -2.778 .

$49 \quad$ We dropped regional and year effects with very low t-ratios (leaving 2002, RRD, SE and MD). With a complete set of year and region effects the coefficient on $L L$ is -0.018 ( $\mathrm{t}=2.09)$. 
Each of these tests makes one or more assumptions that can be questioned. However, taken as a whole, they cast considerable doubt on the claims about the impoverishing effects of rising landlessness found in the literature and policy debates. Rising landlessness appears instead to be a positive factor in poverty reduction. This is less clear in the south, however.

\section{Conclusions}

The prospect of renewed class differentiation — in particular the reemergence of a rural proletariat — has fuelled much debate about the wisdom of liberalizing agricultural land markets in the transition economies of East Asia. Vietnam has taken this step, but neighboring China has not. On theoretical grounds, we have argued that one should not be surprised to find a higher incidence of landlessness among the poor after breaking up the collectives and introducing a market in land-use rights. Many farmers will no doubt benefit from the new opportunities to use their wealth in other ways. But there could also be losers from such a reform. Welfare losses can occur for those who were previously landless, who receive lower wages than without the reform, and for those farmers who find that other benefits provided by the collectives are retrenched once their role in land allocation is removed. It is an empirical question whether the process of rising landlessness in the wake of such a reform is poverty reducing on balance.

Survey data for Vietnam — spanning a decade after legal reforms to introduce markets in land-use rights — confirm the expected rise in the landlessness rate among the poor. Even so, the post-reform landlessness rate tends to be higher for the rural non-poor in Vietnam as a whole. By and large, it is not the currently poor who took up the new opportunities for selling (or buying) land and acquiring land titles, but the relatively well off. Access to formal credit appears to have improved overall (and displaced informal credit), though more markedly for better off 
households. Among equally poor households, the landless are less likely to receive credit from formal sources, including the targeted anti-poverty programs.

We find no sign that rising landlessness has undermined the gains to the poor from the relatively equitable assignment of land-use rights achieved at the time of de-collectivization. Even in the south's Mekong Delta — where there are signs of emerging class differentiation — poverty has been falling among the landless, albeit at a lower rate than for those with land. However, we find no sign that this pattern is emerging elsewhere in Vietnam; indeed, as a rule, the landless are enjoying similar (or even higher) rates of poverty reduction as those with land. On the whole, rising rural landlessness appears to be a positive factor in the process of poverty reduction, as farm households take up new opportunities, notably in the labor market. This does not imply that any policy effort to encourage landlessness will be poverty reducing; it is one thing to give people the opportunity to sell their land to take up more rewarding opportunities but quite another to compel such changes by forcing farmers off their land. Policies should focus instead on making land markets work better for poor people and on complementary efforts in other factor markets to enhance non-farm opportunities, including redressing the evident biases against the landless poor. 


\section{References}

Akram-Lodhi, A. Haroon, 2004, “Are 'Landlords Taking Back the Land'? An Essay on the Agrarian Transition in Vietnam,” European Journal of Development Research 16(4): 757-789. , 2005, "Vietnam’s Agriculture: Processes of Rich Peasant Accumulation and Mechanisms of Social Differentiation,” Journal of Agrarian Change 5(1): 73-116.

Asian Development Bank, 2004, "The Impact of Land Market Processes on the Poor: Implementing de Soto: Project Report,” Asian Development Bank, Hanoi.

Benjamin, Dwayne and Loren Brandt, 2004, “Agriculture and Income Distribution in Rural Vietnam under Economic Reforms: A Tale of Two Regions,” in P. Glewwe, N. Agrawal and D. Dollar (eds) Economic Growth, Poverty and Household Welfare: Policy Lessons from Vietnam, World Bank, Washington, D.C.

Brümmer, B., T. Glauben and W. Lu, 2006, "Policy Reform and Productivity Change in Chinese Agriculture: A Distance Function Approach,” Journal of Development Economics, in press.

Carter, Colin and Andrew Estrin, 2001, “Market Reforms versus Structural Reforms in Rural China,” Journal of Comparative Economics 29: 527-541.

Center for Rural Progress, 2005, “The Impact of Market Processes on the Poor: A Study of the Mekong River Delta,” Research Report for the Asian Development Bank’s Project, Making Markets Work Better for the Poor, Center for Rural Progress, Hanoi.

Dasgupta, Partha and Debraj Ray, 1986, "Inequality as a Determinant of Malnutrition and Unemployment,” Economic Journal 96: 1011-34.

Deininger, Klaus and Songqing Jin, 2003, "Land Sales and Rental Markets in Transition: Evidence from Rural Vietnam,” Policy Research Working Paper 3013, World Bank, Washington DC. and , 2006, “Tenure Security and Land-Related Investment:

Evidence for Ethiopia,” European Economic Review, in press.

De Mauny, Alix and Thu Hong Vu, 1998, "Landlessness in the Mekong Delta: The Situation in Duyen Hai District, Tra Vinh Province, Viet Nam,” Report prepared for Oxfam Great Britain, Hanoi, Viet Nam. 
Dong, Xiao-Yuan, 1996, “Two-Tier Land Tenure System and Sustained Economic Growth in Post-1978 Rural China,” World Development 24(5): 916-928.

Economist, 2006, “China: How the Other 800 Million Live,” The Economist, March 11-17, p.12. Fleisher, Belton and Xiaojun Wang, 2004, "Skill Differentials, Return to Schooling and Market Segmentation in a Transition Economy: The Case of Mainland China,” Journal of Development Economics 73: 315-328.

Gallup, John Luke, 2004, “The Wage Labor Market and Inequality in Vietnam,” in P. Glewwe, N. Agrawal and D. Dollar (eds) Economic Growth, Poverty and Household Welfare: Policy Lessons from Vietnam, World Bank, Washington, D.C.

Glewwe, Paul, 2003, "Procedure for calculating nominal and real expenditures, and poverty indicators, for the 2002 Viet Nam Household Living Standards Survey (VHLSS),” mimeo, University of Minnesota, June 13. , 2005, “Mission Report for Trip to Vietnam October 17-25, 2005,” mimeo, University of Minnesota, November 22.

Glewwe, Paul and Hanan Jacoby, 2004, “Economic Growth and the Demand for Education: Is there a Wealth Effect?” Journal of Development Economics, 74: 33-51.

Guo, Xiaolin, 2001, “Land Expropriation and Rural Conflicts in China,” China Quarterly, 166: 422-439.

Hayami, Yujiro, 1994, “Strategies for the Reform of Land Policy Relations,” in FAO, Agricultural Policy Analysis for Transition in a Market-Oriented Economy, FAO Economic and Social Development Paper 123, Rome.

Ho, Samuel and George Lin, 2003, “Emerging Land Markets in Rural and Urban China: Policies and Practices,” China Quarterly 175: 681-707.

Lam, T. M.L., 2001, “Land Fragmentation: A Constraint on Vietnamese agriculture,” Vietnam’s Socio-Economic Development 26: 73-80.

Li, Guo, Scott Rozelle and Loren Brandt, 1998, “Tenure, Land Rights and Farmer Investment Incentives in China,” Agricultural Economics 19: 63-71.

Moene, Karl, 1992, “Poverty and Landownership,” American Economic Review 82: 52-64.

Ngo, Thi Minh, 2004, “Education and Agricultural Productivity,” London School of Economics.

Ngo V.L., 1993, “Reform and Rural Development: Impact on Class, Sectoral, and Regional Inequalities,” in: William Turley and Mark Selden (eds) Reinventing Vietnamese 
Socialism, Boulder, C.O.: Westview Press.

Nguyen, Van Suu, 2004a, "The Politics of Land: Inequality in Land Access and Local Conflicts in the Red River Delta Since Decollectivization,” in Philip Taylor (ed.) Social Inequality in Vietnam and the Challenges to Reform, Institute of Southeast Asian Studies, Singapore.

Nguyen, Nga Nguyet, 2004b, “Trends in the Education Sector,” in P. Glewwe, N. Agrawal and D. Dollar (eds) Economic Growth, Poverty and Household Welfare: Policy Lessons from Vietnam, World Bank, Washington, D.C.

Pingali, P. and Xuan, V-T., 1992, "Viet Nam: Decollectivization and Rice Productivity Growth," Economic Development and Cultural Change 40(4): 697-718.

Ravallion, Martin and Dominique van de Walle, 2004, "Breaking up the Collective Farms: Welfare Outcomes of Vietnam's Massive Land Privatization,” Economics of Transition, 12(2): 201-236. and , 2005, “Land Reallocation in Vietnam’s Agrarian

Transition” Economic Journal, forthcoming.

Rozelle, Scott and Johan Swinnen, 2004, "Success and Failure of Reform: Insights from the Transition of Agriculture," Journal of Economic Literature 42(June): 202-456.

Smith, William 1997, Land and the Poor: A Survey of Land Use Rights in Ha Tinh and Son La Provinces, ActionAid, Hanoi, Vietnam.

Smith, William and Tran Thanh Binh, 1994, "The Impact of the 1993 Land Law on Rural Households in the Mai Don District of Son La Province,” mimeo, ActionAid, Hanoi, Vietnam.

Taylor, Philip, 2004, “Redressing Disadvantage or Re-arranging Inequality? Development Interventions and Local Responses in the Mekong Delta," in Philip Taylor (ed.) Social Inequality in Vietnam and the Challenges to Reform, Institute of Southeast Asian Studies, Singapore.

van de Walle, Dominique, 2003, “Are Returns to Investment Lower for the Poor? Human and Physical Capital Interactions in Rural Vietnam,” Review of Development Economics 7(4): 636-653.

van de Walle, Dominique and Dorothyjean Cratty, 2004, "Is the Emerging Non-Farm Market Economy the Route Out of Poverty in Viet Nam?” Economics of Transition, 12(2): 
237-274.

van de Walle, Dominique and Dileni Gunewardena, 2001, "Sources in Ethnic Inequality in Vietnam,” Journal of Development Economics 65(1): 177-207.

World Bank, 1995, "Viet Nam Living Standards Survey (VLSS), 1992-93: Basic Information,” mimeo, Development Research Group, World Bank, Washington, D.C. , 2000, "Viet Nam Living Standards Survey (VLSS), 1997-99: Basic Information," mimeo, Development Research Group, World Bank, Washington, D.C. , 2004, Vietnam Development Report 2004: Poverty, Joint Donor report to the Vietnam Consultative Group Meeting, Vietnam Development Information Center, Hanoi. , 2005, Vietnam Development Report 2006: Business, World Bank, Hanoi.

Yeh, Anthony Gar-On and Xia Li, 1999, "Economic Development and Agricultural Land Loss in the Pearl River Delta, China,” Habitat International 23(3): 373-390.

Zhou, Jian-Ming, 1998, “Is Nominal Public but De Facto Private Land Ownership Appropriate? A Comparative Study Among Cambodia, Laos, Vietnam, Japan, Taiwan Province of China, South Korea, China, Myanmar and North Korea,” Working Paper ECO 98/12, European University Institute, Florence. http://www.iue.it/ECO/WP-Texts/98_12.html , 2001, Sustainable Development in Asia, America and Europe with Global Applications: A New Approach to Land Ownership, Edward Elgar, Cheltenham, UK. 
Table 1: Poverty, inequality and land-holding status in rural Vietnam

\begin{tabular}{|c|c|c|c|c|c|c|c|c|}
\hline & \multicolumn{4}{|c|}{ Population with land } & \multicolumn{4}{|c|}{ Landless population } \\
\hline & $\%$ & $\begin{array}{l}\text { Mean } \\
\text { consump- } \\
\text { tion }\end{array}$ & $\begin{array}{l}\text { Consump- } \\
\text { tion } \\
\text { inequality } \\
\text { (MLD) }\end{array}$ & $\begin{array}{l}\text { Poverty } \\
\text { rate (\%) }\end{array}$ & $\%$ & $\begin{array}{l}\text { Mean } \\
\text { consump- } \\
\text { tion }\end{array}$ & $\begin{array}{l}\text { Consump- } \\
\text { tion } \\
\text { inequality } \\
\text { (MLD) }\end{array}$ & $\begin{array}{l}\text { Poverty } \\
\text { rate (\%) }\end{array}$ \\
\hline & \multicolumn{8}{|c|}{ Rural Vietnam } \\
\hline 1993 & 92.2 & 1626.9 & 0.114 & 70.04 & 7.8 & 2163.2 & 0.174 & 50.87 \\
\hline 1998 & 93.1 & 2135.0 & 0.124 & 45.90 & 6.9 & 2588.3 & 0.199 & 40.51 \\
\hline 2002 & 86.1 & 2338.9 & 0.133 & 38.60 & 13.9 & 3116.5 & 0.162 & 25.11 \\
\hline 2004 & 87.7 & 2823.9 & 0.148 & 25.99 & 12.3 & 3514.4 & 0.162 & 18.14 \\
\hline & \multicolumn{8}{|c|}{ Majority ethnic groups } \\
\hline 1993 & 91.4 & 1708.5 & 0.108 & 66.20 & 8.6 & 2248.3 & 0.165 & 47.38 \\
\hline 1998 & 92.7 & 2274.0 & 0.114 & 39.13 & 7.3 & 2784.7 & 0.155 & 34.66 \\
\hline 2002 & 84.4 & 2499.8 & 0.117 & 31.44 & 15.6 & 3168.2 & 0.160 & 23.40 \\
\hline 2004 & 86.1 & 3046.2 & 0.125 & 18.06 & 13.9 & 3582.3 & 0.159 & 16.60 \\
\hline & \multicolumn{8}{|c|}{ Minority ethnic groups } \\
\hline 1993 & 96.6 & 1215.4 & 0.103 & 89.39 & 3.4 & 1038.0 & 0.090 & 97.12 \\
\hline 1998 & 95.0 & 1516.5 & 0.097 & 76.04 & 5.0 & 1259.1 & 0.216 & 80.14 \\
\hline 2002 & 96.0 & 1544.2 & 0.113 & 73.96 & 4.0 & 1995.0 & 0.144 & 62.16 \\
\hline 2004 & 96.0 & 1775.6 & 0.132 & 63.36 & 4.0 & 2270.0 & 0.146 & 46.41 \\
\hline
\end{tabular}

Note: Mean consumption per capita is in thousands of real 1998 dongs. Inequality is measured by the mean log deviation; poverty is given by the headcount index based on a constant real poverty line. 
Table 2: Poverty, inequality and land-holding status by region

\begin{tabular}{|c|c|c|c|c|c|c|c|c|}
\hline & \multicolumn{4}{|c|}{ Population with land } & \multicolumn{4}{|c|}{ Landless population } \\
\hline & $\%$ & Mean C & MLD & $\begin{array}{c}\text { Poverty } \\
(\%)\end{array}$ & $\% *$ & Mean C & MLD & $\begin{array}{c}\text { Poverty } \\
(\%)\end{array}$ \\
\hline & \multicolumn{8}{|c|}{ Northern Uplands } \\
\hline 1993 & 97.8 & 1342.1 & 0.081 & 85.41 & $2.2(13)$ & 1816.6 & 0.238 & 62.86 \\
\hline 1998 & 98.0 & 1701.8 & 0.099 & 66.30 & $2.0(18)$ & 3619.3 & 0.132 & 10.61 \\
\hline 2002 & 96.6 & 2019.4 & 0.125 & 50.58 & 3.4 & 3639.7 & 0.110 & 7.89 \\
\hline \multirow[t]{2}{*}{2004} & 97.2 & 2457.7 & 0.150 & 37.40 & 2.8 & 4365.6 & 0.128 & 5.43 \\
\hline & \multicolumn{8}{|c|}{ Red River Delta } \\
\hline 1993 & 98.0 & 1557.4 & 0.080 & 73.74 & 2.0 & 2584.9 & 0.087 & 21.59 \\
\hline 1998 & 99.6 & 2291.1 & 0.089 & 36.10 & $0.4(10)$ & 2106.0 & 0.029 & 40.85 \\
\hline 2002 & 92.6 & 2449.9 & 0.104 & 30.59 & 7.4 & 4668.8 & 0.159 & 3.90 \\
\hline \multirow[t]{2}{*}{2004} & 94.3 & 2996.8 & 0.106 & 16.29 & 5.7 & 4467.3 & 0.105 & 3.27 \\
\hline & \multicolumn{8}{|c|}{ North Central Coast } \\
\hline 1993 & 96.5 & 1428.9 & 0.080 & 79.43 & 3.5 & 1680.3 & 0.094 & 58.16 \\
\hline 1998 & 98.3 & 2018.6 & 0.114 & 50.95 & $1.7(18)$ & 1719.8 & 0.029 & 71.09 \\
\hline 2002 & 91.3 & 2005.4 & 0.108 & 51.35 & 8.7 & 2596.7 & 0.159 & 37.27 \\
\hline \multirow[t]{2}{*}{2004} & 93.2 & 2369.7 & 0.123 & 37.49 & 6.8 & 3070.3 & 0.129 & 21.67 \\
\hline & \multicolumn{8}{|c|}{ South Central Coast } \\
\hline 1993 & 90.2 & 1642.4 & 0.136 & 65.80 & 9.8 & 2582.7 & 0.174 & 35.75 \\
\hline 1998 & 98.3 & 2109.0 & 0.133 & 43.56 & 1.7 (13) & 3052.2 & 0.235 & 44.05 \\
\hline 2002 & 83.6 & 2292.4 & 0.118 & 34.50 & 16.4 & 2927.5 & 0.150 & 20.40 \\
\hline \multirow[t]{2}{*}{2004} & 86.7 & 2764.8 & 0.154 & 26.13 & 13.3 & 3020.2 & 0.093 & 16.33 \\
\hline & \multicolumn{8}{|c|}{ Central Highlands } \\
\hline 1993 & 92.8 & 1506.6 & 0.161 & 72.87 & $7.2(12)$ & 1921.7 & 0.086 & 72.73 \\
\hline 1998 & 90.9 & 2033.4 & 0.146 & 49.38 & 9.1 & 1021.7 & 0.274 & 82.68 \\
\hline 2002 & 96.8 & 1753.8 & 0.155 & 62.17 & 3.2 & 2092.4 & 0.123 & 55.81 \\
\hline \multirow[t]{2}{*}{2004} & 97.0 & 2322.5 & 0.171 & 42.43 & $3.0(17)$ & 2879.8 & 0.099 & 5.38 \\
\hline & \multicolumn{8}{|c|}{ South East } \\
\hline 1993 & 78.3 & 2067.2 & 0.147 & 50.84 & 21.7 & 2534.7 & 0.196 & 36.26 \\
\hline 1998 & 74.3 & 3397.0 & 0.131 & 12.47 & 25.7 & 3732.7 & 0.159 & 14.51 \\
\hline 2002 & 62.0 & 3218.7 & 0.126 & 15.85 & 38.0 & 3624.6 & 0.154 & 14.05 \\
\hline \multirow[t]{2}{*}{2004} & 62.7 & 4043.1 & 0.138 & 8.35 & 37.3 & 4511.5 & 0.194 & 7.04 \\
\hline & \multicolumn{8}{|c|}{ Mekong Delta } \\
\hline 1993 & 86.0 & 1943.5 & 0.131 & 54.63 & 14.0 & 1888.0 & 0.165 & 64.05 \\
\hline 1998 & 84.1 & 2189.9 & 0.086 & 40.27 & 15.9 & 2085.4 & 0.130 & 50.81 \\
\hline 2002 & 75.1 & 2790.1 & 0.130 & 25.02 & 24.9 & 2603.1 & 0.153 & 35.75 \\
\hline 2004 & 77.1 & 3232.0 & 0.129 & 14.83 & 22.9 & 2883.4 & 0.152 & 29.26 \\
\hline
\end{tabular}

Note: See Table 1. *: small sample sizes (under 20) are given in parentheses. 
Table 3: Decomposition of the change in aggregate landlessness

\begin{tabular}{lccccc}
\hline & \multicolumn{2}{c}{ Landlessness rate (\%) } & \multicolumn{2}{c}{ Decomposition } & Total change \\
& $L_{93}$ & $L_{04}$ & $\begin{array}{c}\text { Consumption } \\
\text { reallocation }(\%) \\
\sum^{2}\left(L_{04 i}-L_{93 i}\right) n_{93 i}\end{array}$ & $\begin{array}{c}L_{04}-L_{93} \\
\sum_{04 i}\left(n_{04 i}-n_{93 i}\right)\end{array}$ \\
\hline Rural Vietnam & 8.42 & 13.55 & 2.27 & 2.85 & 5.13 \\
Northern Uplands & 2.15 & 3.48 & -1.00 & 2.33 & 1.33 \\
Red River Delta & 2.54 & 6.73 & 1.19 & 3.01 & 4.20 \\
North-Coast & 3.96 & 8.25 & 1.65 & 2.63 & 4.28 \\
Central Coast & 12.24 & 14.76 & -1.06 & 3.57 & 2.51 \\
Central Highlands & 9.38 & 3.84 & -6.89 & 1.32 & -5.54 \\
South East & 23.13 & 39.10 & 15.34 & 0.64 & 15.99 \\
Mekong Delta & 16.02 & 25.43 & 15.24 & -5.84 & 9.40 \\
\hline
\end{tabular}




\begin{tabular}{|c|c|c|c|c|}
\hline \multirow{2}{*}{$\begin{array}{l}1993 \text { quintiles of households ranked } \\
\text { by consumption per capita }\end{array}$} & \multicolumn{2}{|c|}{ Landlessness rate } & \multicolumn{2}{|c|}{ Frequency } \\
\hline & 1993 & 2004 & 1993 & 2004 \\
\hline \multicolumn{5}{|l|}{ Rural Vietnam } \\
\hline Quintile 1 (poorest) & 0.0664 & 0.0646 & 0.2002 & 0.0481 \\
\hline Quintile 2 & 0.0652 & 0.0917 & 0.1999 & 0.0575 \\
\hline Quintile 3 & 0.0599 & 0.1116 & 0.2002 & 0.1020 \\
\hline Quintile 4 & 0.0704 & 0.1088 & 0.1999 & 0.1921 \\
\hline Quintile 5 & 0.1591 & 0.1578 & 0.1999 & 0.6002 \\
\hline Total & 0.0842 & 0.1371 & 1.0000 & 1.0000 \\
\hline \multicolumn{5}{|l|}{ Northern Uplands } \\
\hline Quintiles 1-3 & 0.0219 & 0.0035 & 0.6003 & 0.2275 \\
\hline Quintile 4 & 0.0000 & 0.0060 & 0.1990 & 0.1278 \\
\hline Decile 9 & 0.0164 & 0.0205 & 0.1003 & 0.1541 \\
\hline Decile 10 & 0.0667 & 0.0614 & 0.1003 & 0.4905 \\
\hline Total & 0.0214 & 0.0375 & 1.0000 & 1.0000 \\
\hline \multicolumn{5}{|l|}{ Red River } \\
\hline Quintiles 1-3 & 0.0065 & 0.0310 & 0.6006 & 0.1030 \\
\hline Quintile 4 & 0.0293 & 0.0244 & 0.1992 & 0.1319 \\
\hline Decile 9 & 0.0392 & 0.0479 & 0.0996 & 0.1952 \\
\hline Decile 10 & 0.1176 & 0.0905 & 0.0996 & 0.5699 \\
\hline Total & 0.0254 & 0.0678 & 1.0000 & 1.0000 \\
\hline \multicolumn{5}{|l|}{ North Coast } \\
\hline Quintiles 1-3 & 0.0312 & 0.0433 & 0.6010 & 0.2132 \\
\hline Quintile 4 & 0.0434 & 0.0566 & 0.2003 & 0.1625 \\
\hline Decile 9 & 0.0526 & 0.0777 & 0.0993 & 0.1661 \\
\hline Decile 10 & 0.0702 & 0.1116 & 0.0993 & 0.4582 \\
\hline Total & 0.0401 & 0.0821 & 1.0000 & 1.0000 \\
\hline \multicolumn{5}{|l|}{ Central Coast } \\
\hline Quintiles 1-3 & 0.0866 & 0.0882 & 0.6016 & 0.2391 \\
\hline Quintile 4 & 0.1039 & 0.1042 & 0.2005 & 0.2199 \\
\hline Decile 9 & 0.1316 & 0.1911 & 0.0990 & 0.2172 \\
\hline Decile 10 & 0.3684 & 0.1916 & 0.0990 & 0.3238 \\
\hline Total & 0.1224 & 0.1479 & 1.0000 & 1.0000 \\
\hline \multicolumn{5}{|l|}{ Central Highlands } \\
\hline Quintiles 1-3 & 0.0909 & 0.0078 & 0.6016 & 0.3075 \\
\hline Quintile 4 & 0.1154 & 0.0554 & 0.2031 & 0.2300 \\
\hline Decile 9 & 0.0000 & 0.0411 & 0.1016 & 0.1408 \\
\hline Decile 10 & 0.1667 & 0.0542 & 0.0938 & 0.3216 \\
\hline Total & 0.0938 & 0.0386 & 1.0000 & 1.0000 \\
\hline \multicolumn{5}{|l|}{ South East } \\
\hline Quintiles 1-3 & 0.1927 & 0.3974 & 0.6000 & 0.1288 \\
\hline Quintile 4 & 0.2344 & 0.3187 & 0.2000 & 0.2235 \\
\hline Decile 9 & 0.250 & 0.4065 & 0.1000 & 0.1970 \\
\hline Decile 10 & 0.4375 & 0.4182 & 0.1000 & 0.4508 \\
\hline Total & 0.2313 & 0.3920 & 1.0000 & 1.0000 \\
\hline \multicolumn{5}{|l|}{ Mekong Delta } \\
\hline Quintiles 1-2 (poorest) & 0.1938 & 0.3832 & 0.4005 & 0.0954 \\
\hline Quintile 3 & 0.1250 & 0.3438 & 0.2003 & 0.1445 \\
\hline Decile 7 & 0.0750 & 0.2468 & 0.1001 & 0.1028 \\
\hline Decile 8 & 0.1375 & 0.2183 & 0.1001 & 0.1270 \\
\hline Decile 9 & 0.1875 & 0.2281 & 0.1001 & 0.1747 \\
\hline Decile 10 & 0.1772 & 0.2110 & 0.0989 & 0.3555 \\
\hline Total & 0.1602 & 0.2536 & 1.0000 & 1.0000 \\
\hline
\end{tabular}


Figure 1: Functions used in the theoretical analysis $\left(g_{1}\left(A_{0}\right)=g_{0}\left(A_{0}\right)\right)$

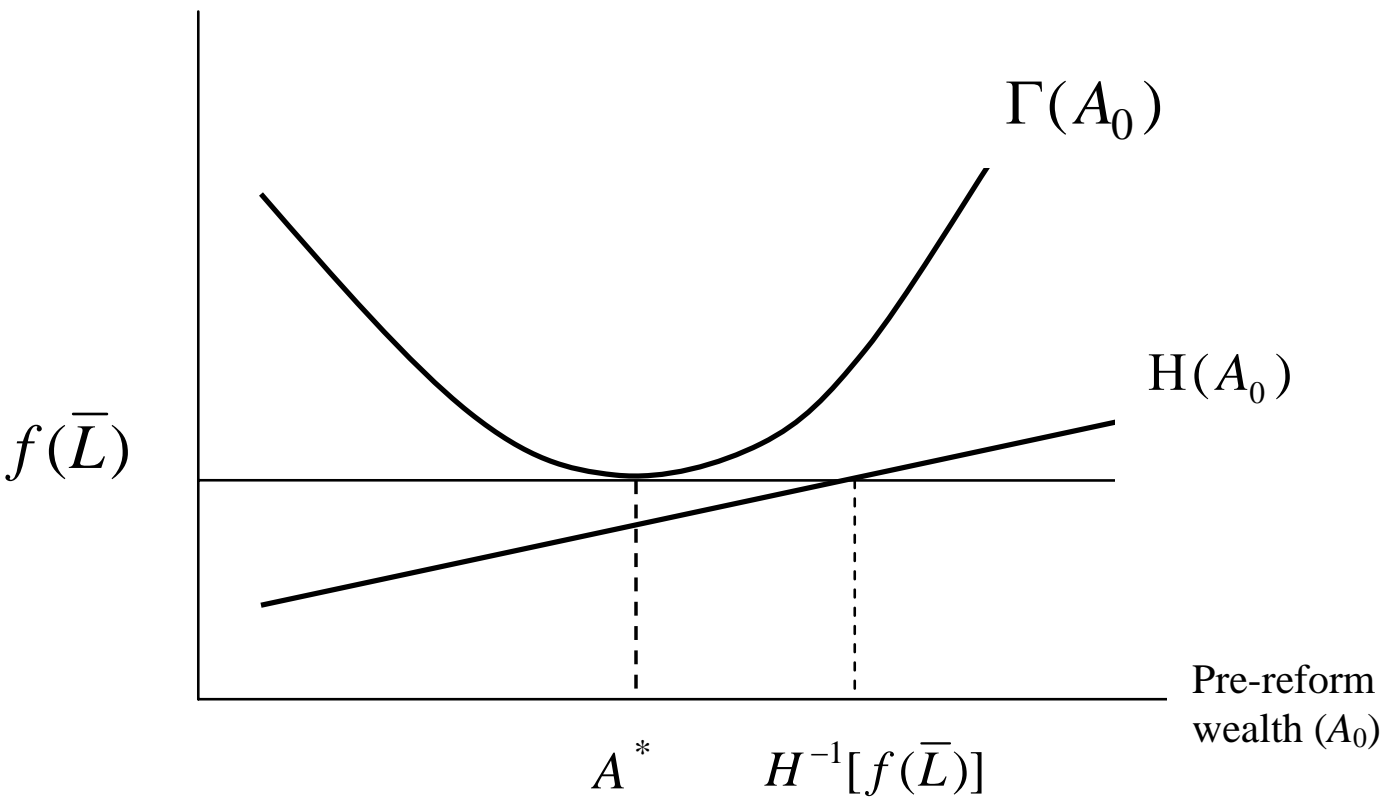


Figure 2: Frequency distributions of consumption for 1993 and 2004

(a) Rural Vietnam
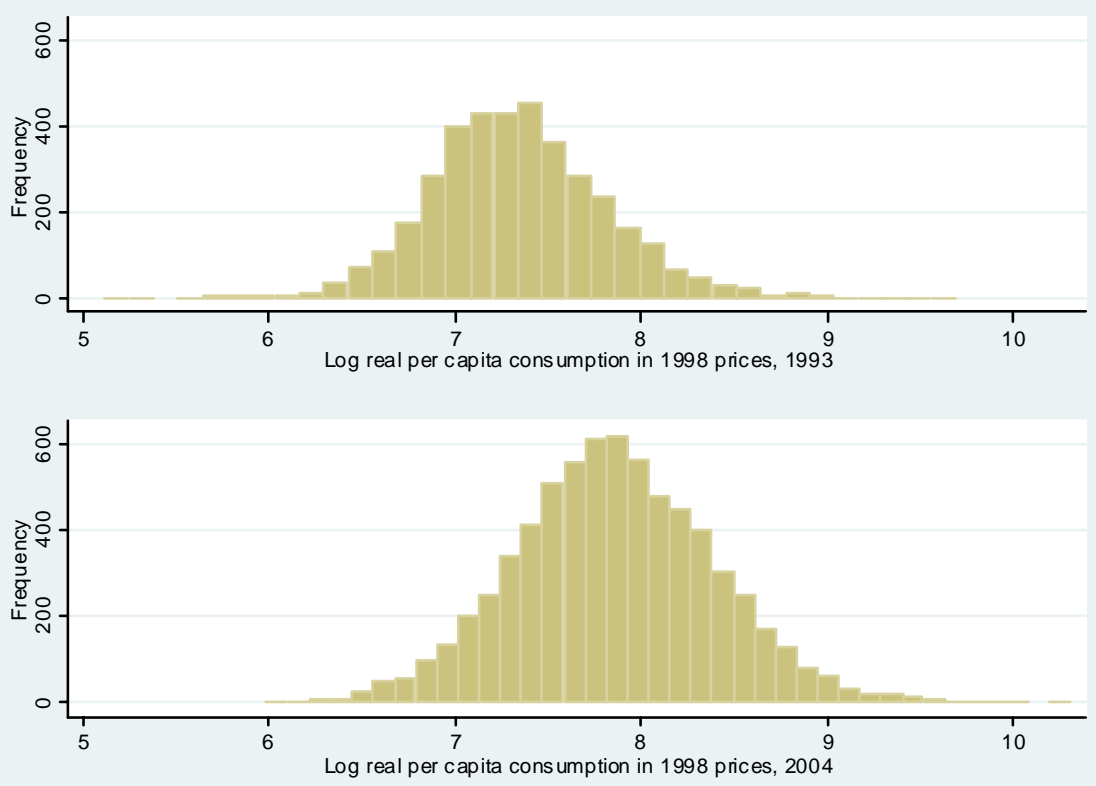

(b) Rural landless only
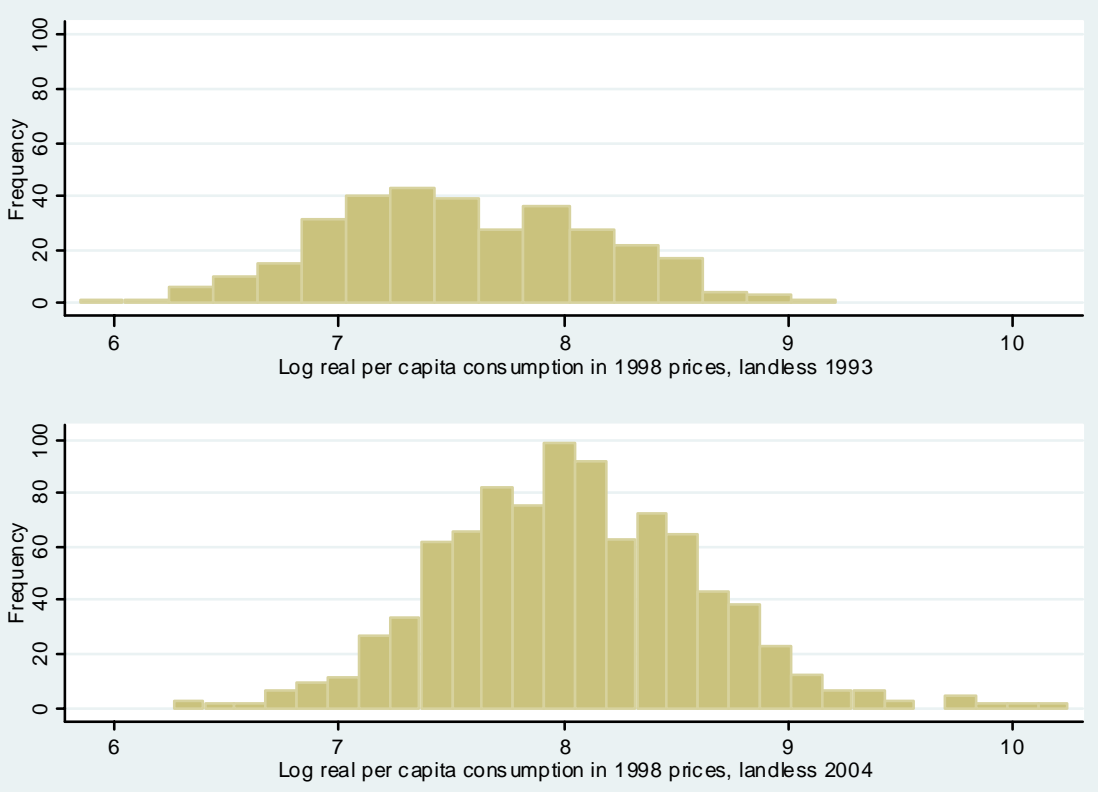
Figure 3: Landlessness and consumption per person rural Vietnam, 1993 and 2004

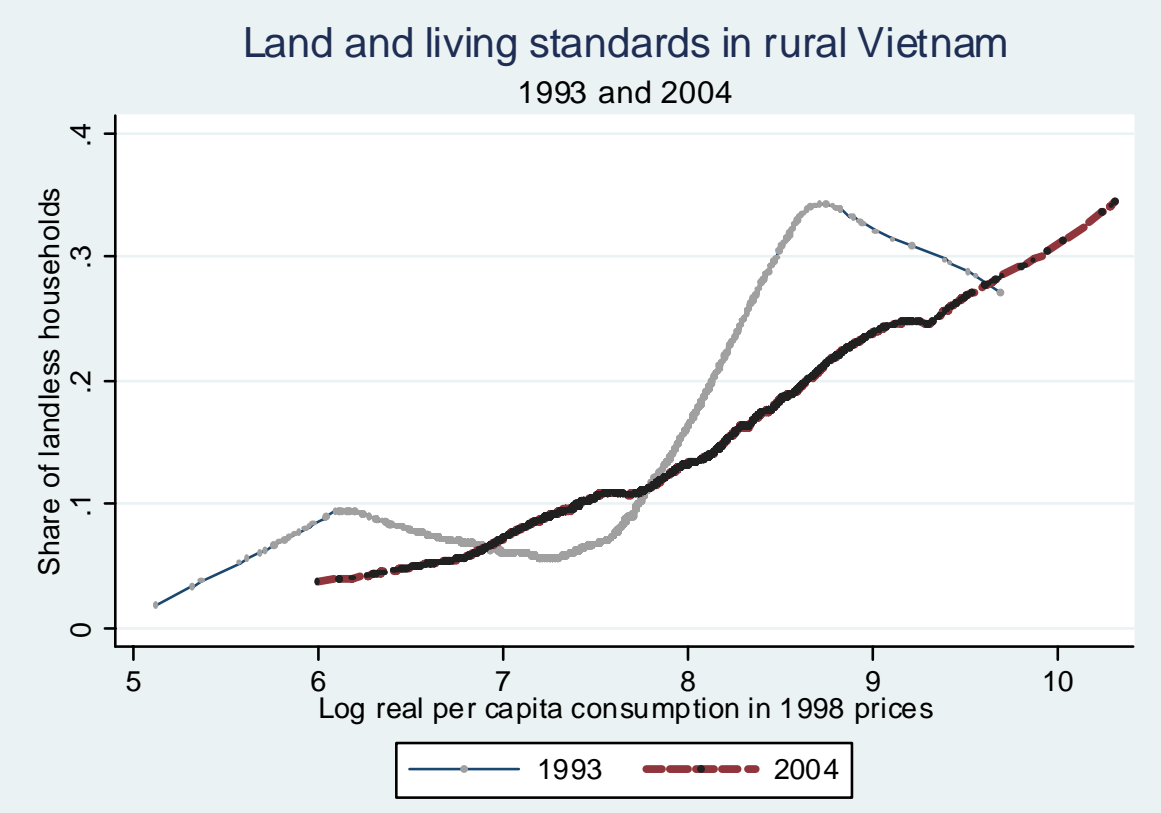


Figure 4: Non-cultivating households compared to landless households

(a) 1993

Landless and non-cultivating households by living standards rural Vietnam 1993

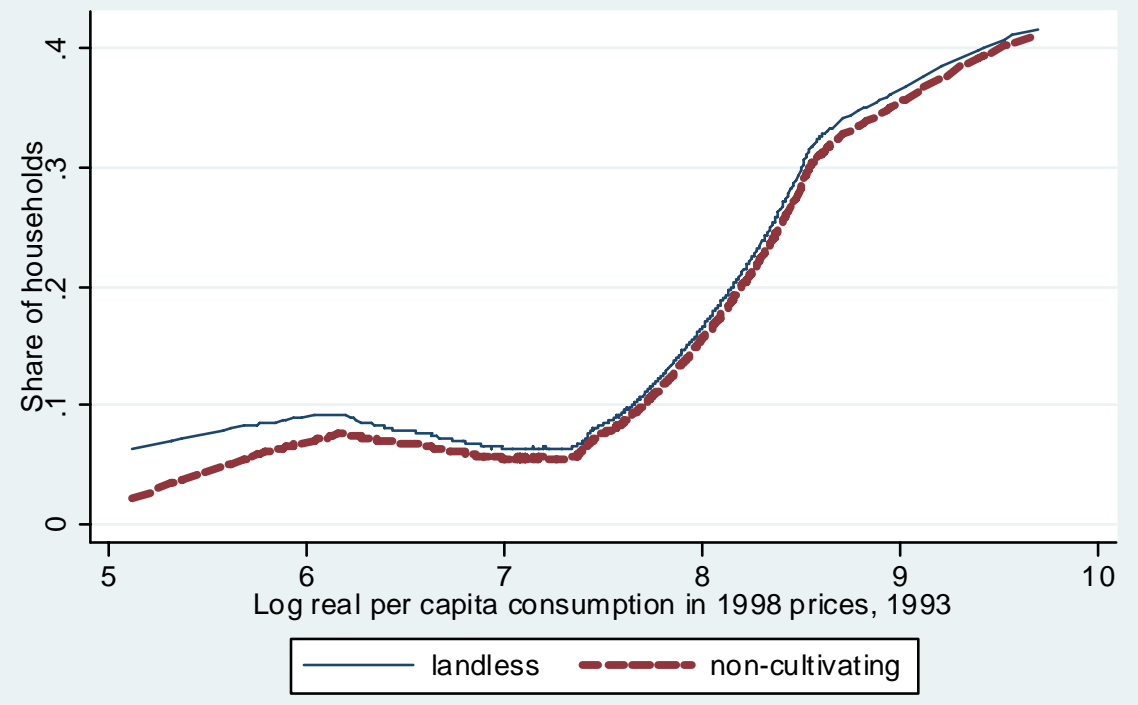

(b) 2004

Landless and non-cultivating households by living standards rural Vietnam 2004

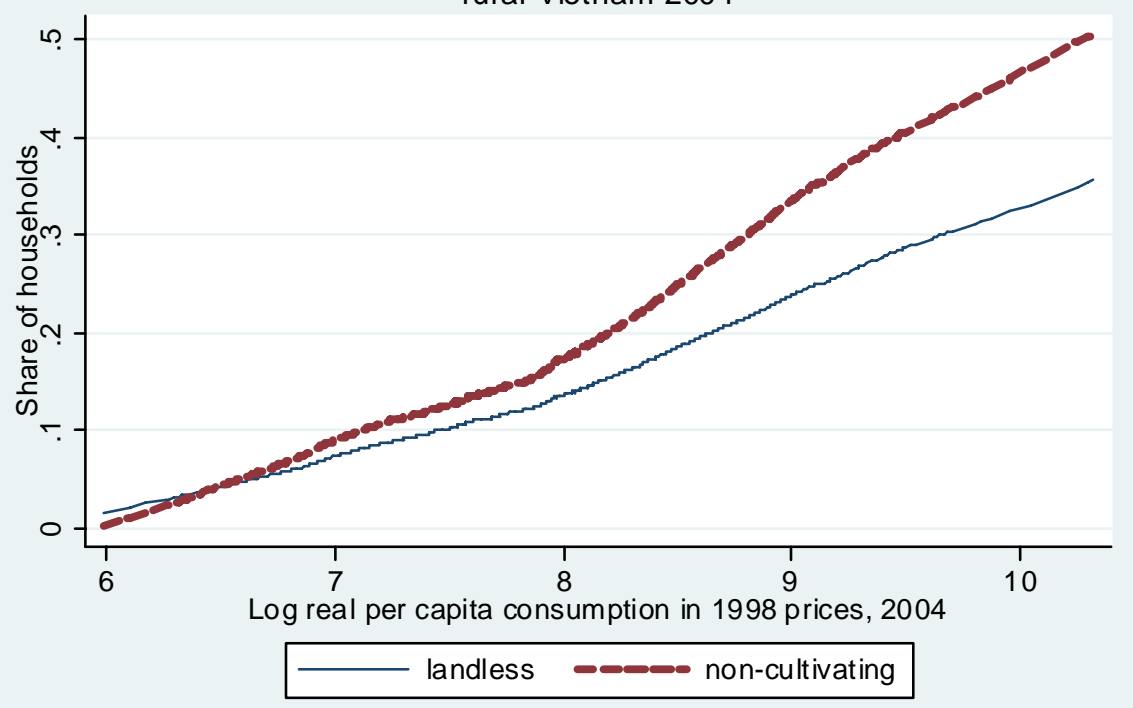


Figure 5: Landlessness and consumption per person for ethnic minorities

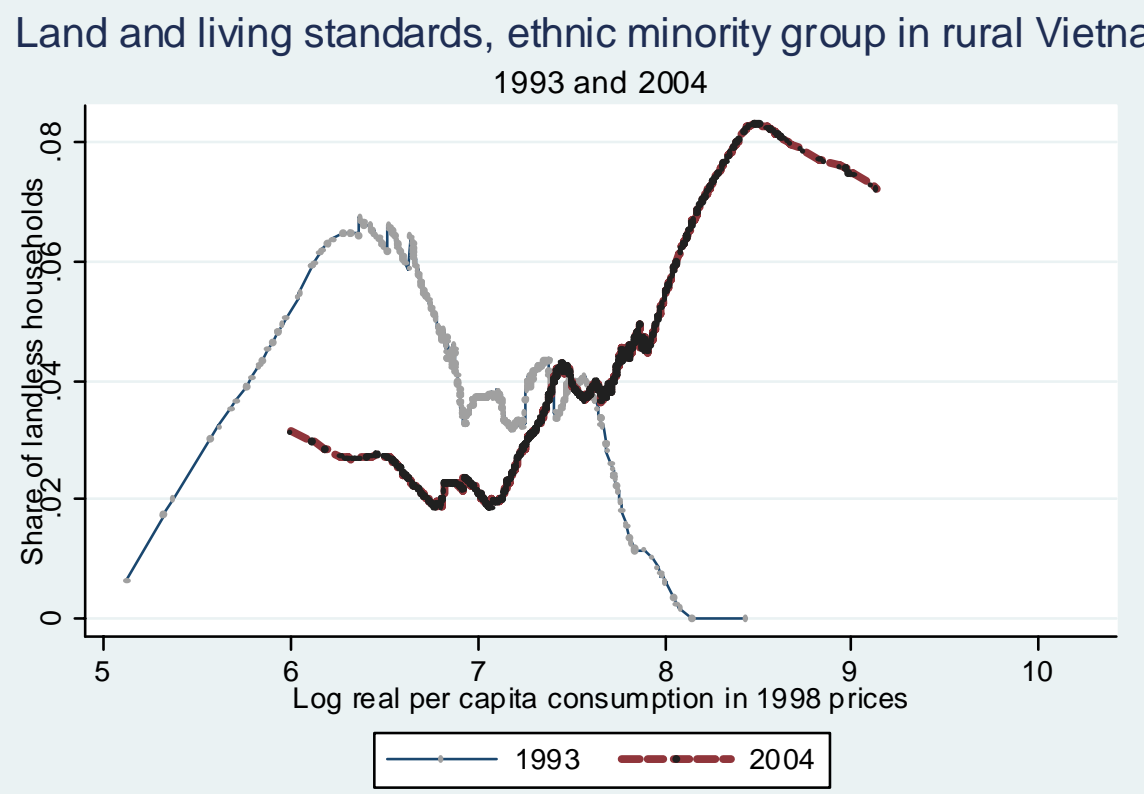


Figure 6: Landlessness and consumption in the two deltas

(a) Red River Delta

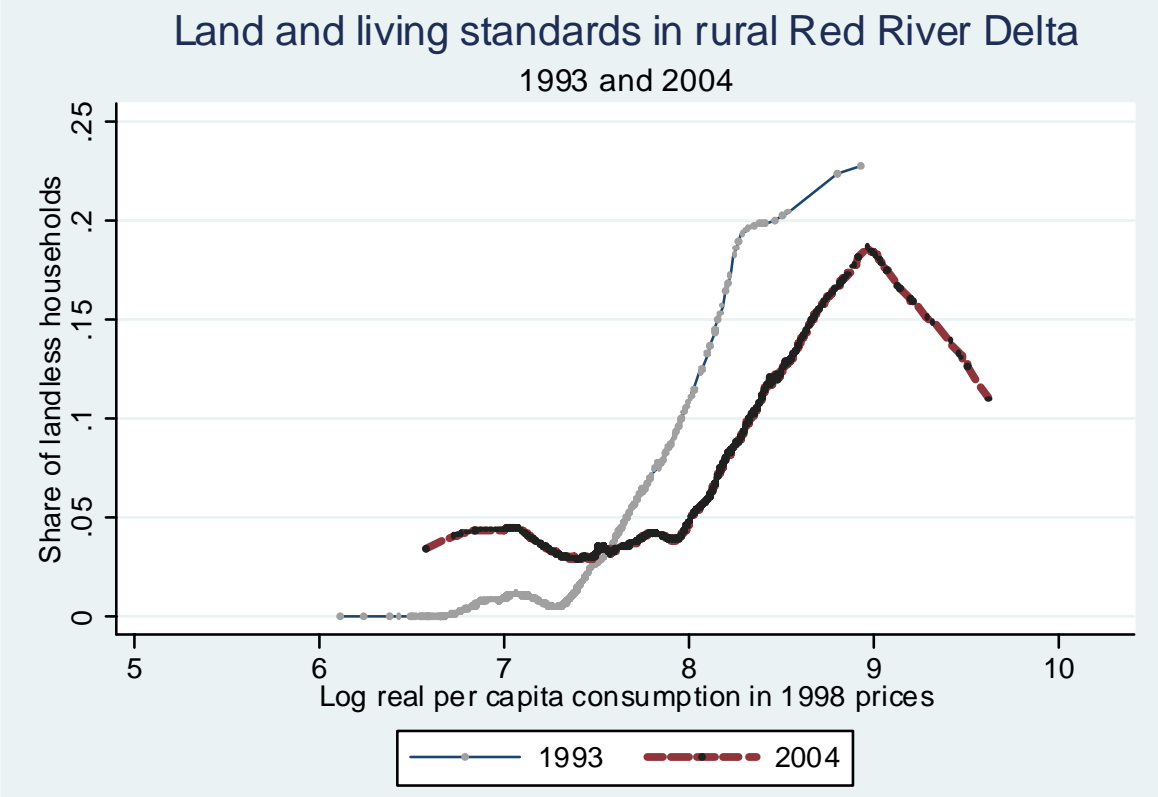

(b) Mekong Delta

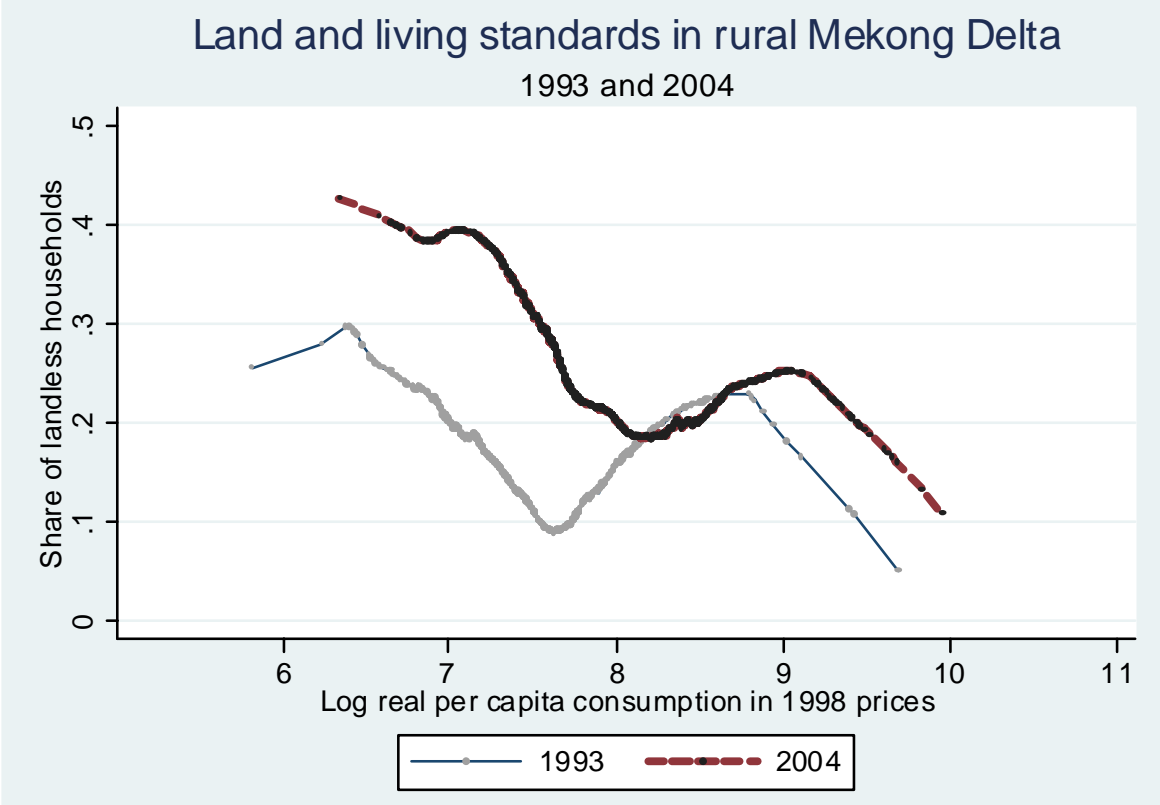


Figure 7: Land and living standards for those with land

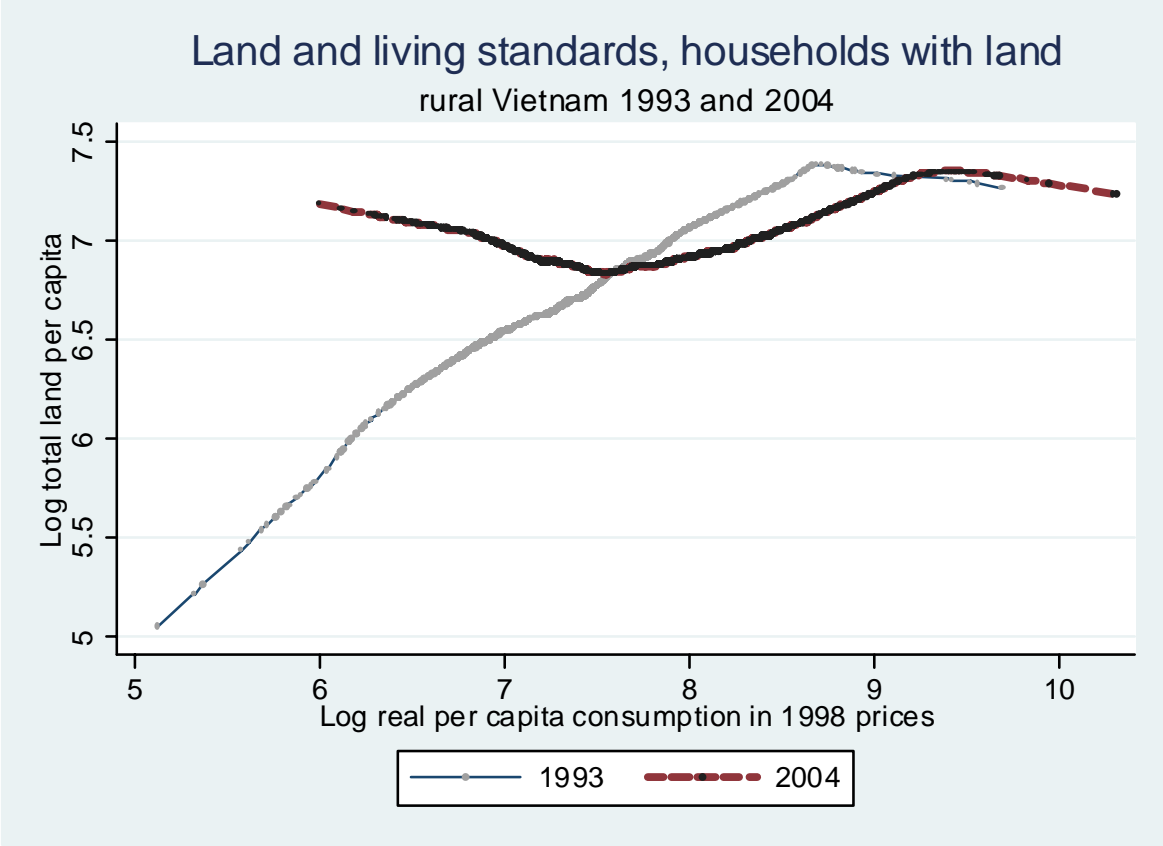

Figure 8: Share of annual crop land that is irrigated

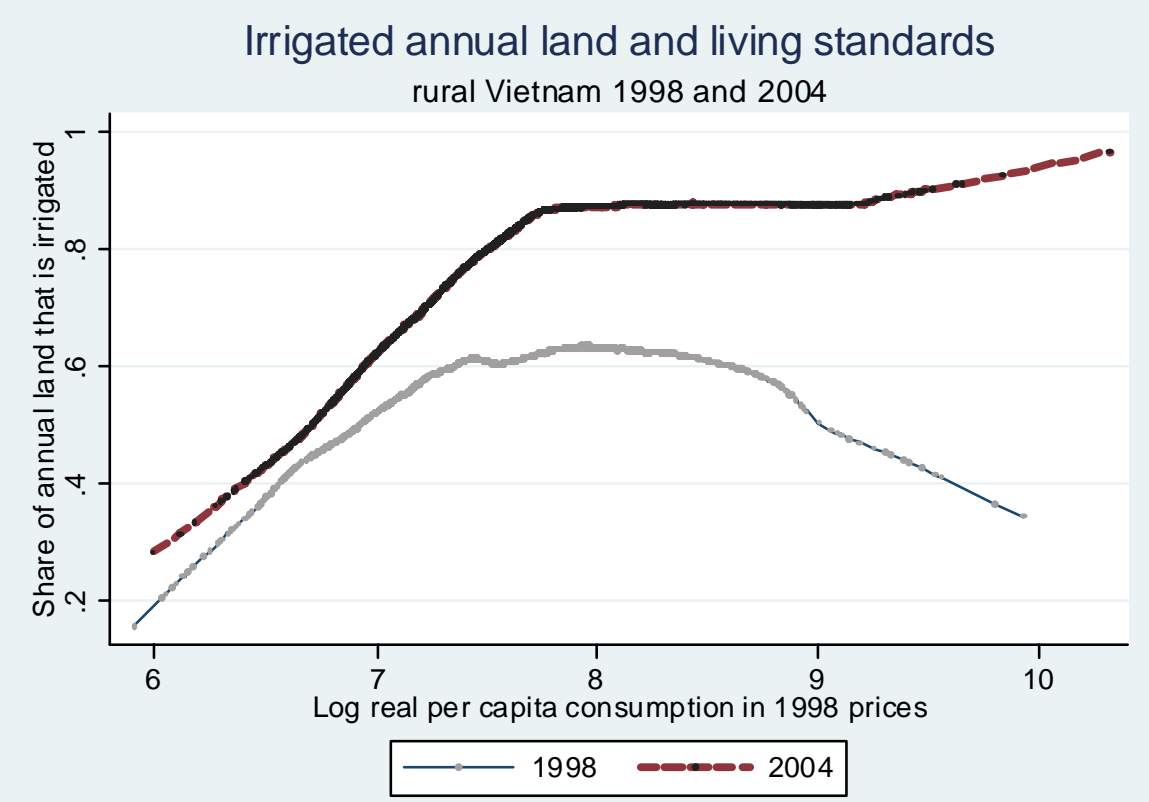




\section{Figure 9: Incidence of land transactions}

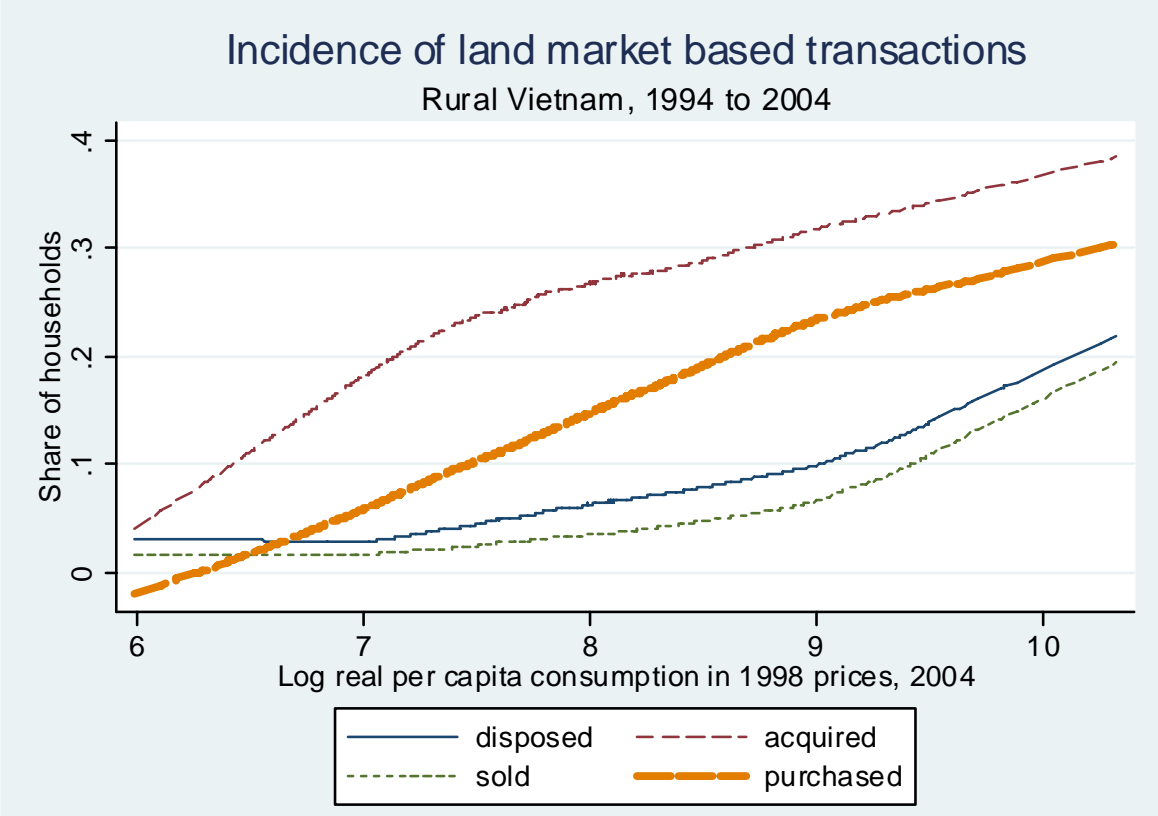

Note: Market based transactions only: "disposed” consists of land sold, bequeathed, exchanged or rent expired (excludes land taken back by government and other); "acquired” includes land inherited, bid for, purchased or exchanged (excludes land reclaimed or commune allocated).

\section{Figure 10: Sources of land}

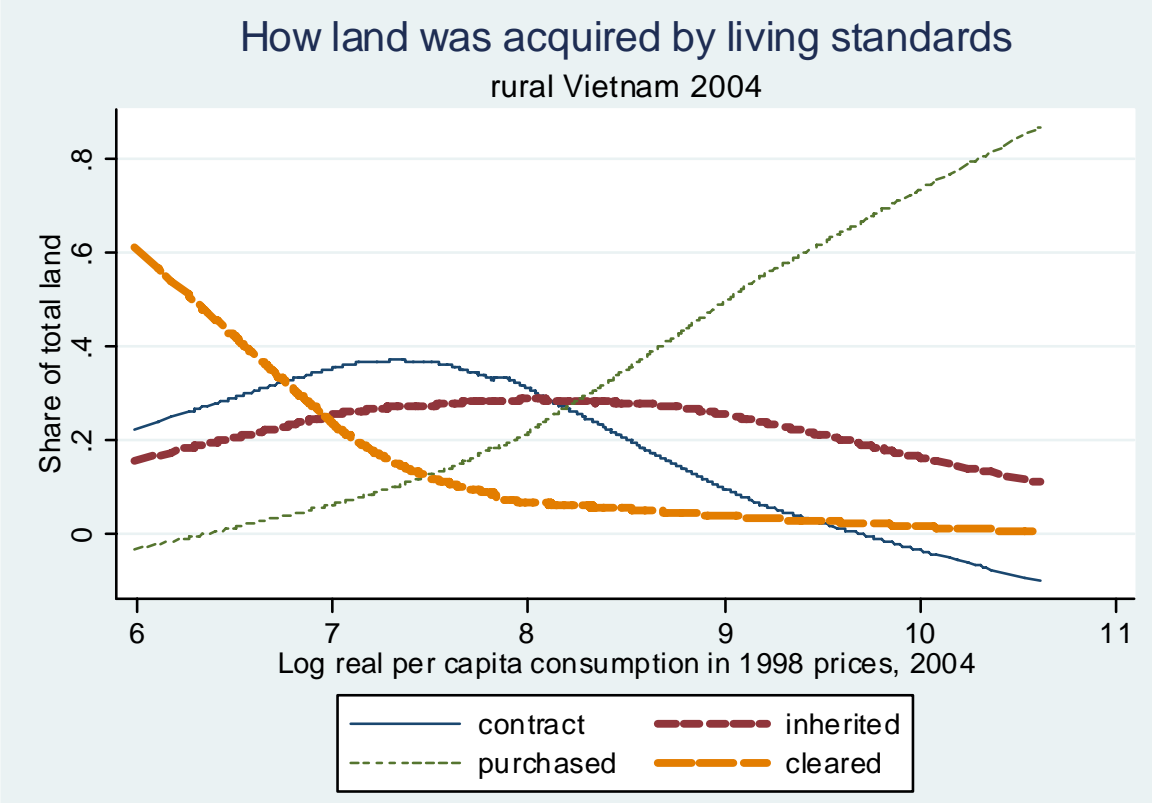

Note: Left out are the shares of land acquired through rental or auction, barter, borrowing or other; these are add up to a total of $11 \%$ of currently cultivated land. "Contract land" refers to land obtained from local authorities through the allocation process, as well as contracted from State Farms and Forest Enterprises. 
Figure 11: Incidence of land titles

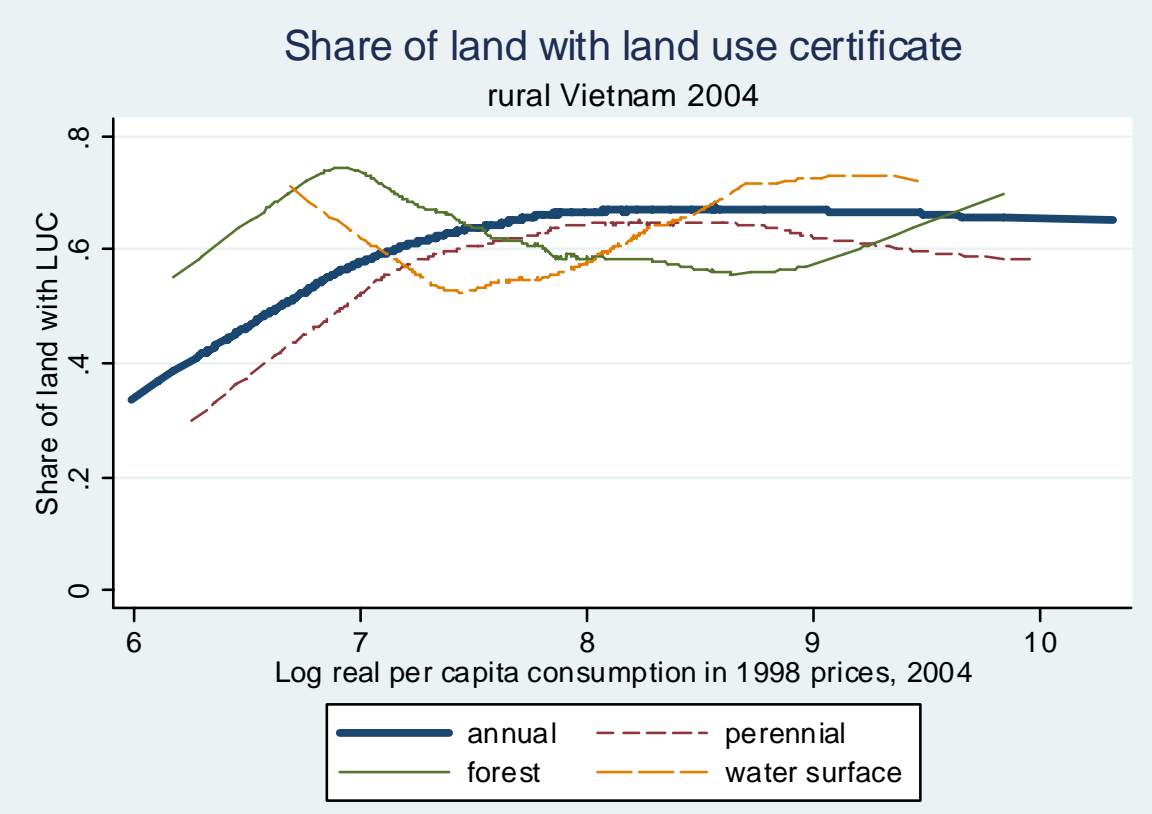

Figure 12: Wage earners by household consumption per person

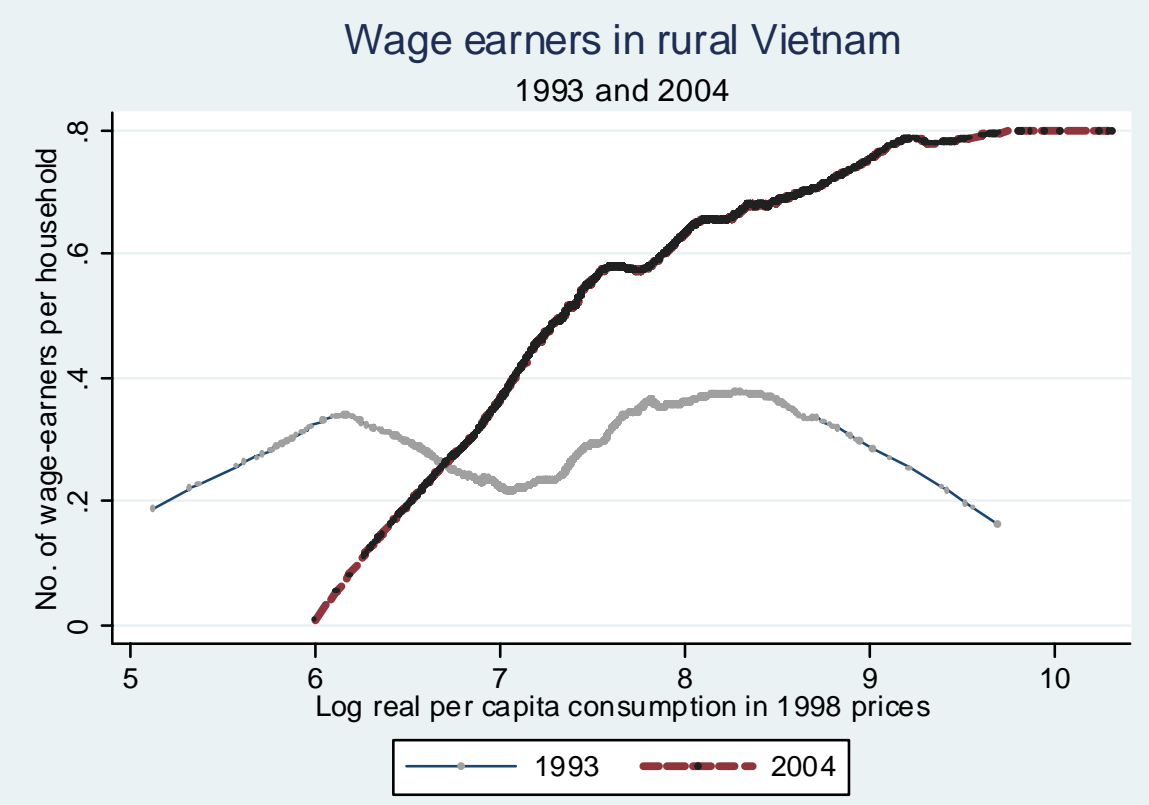


Figure 13: Wage earners by household consumption per person for the two deltas

(a) Red-River Delta

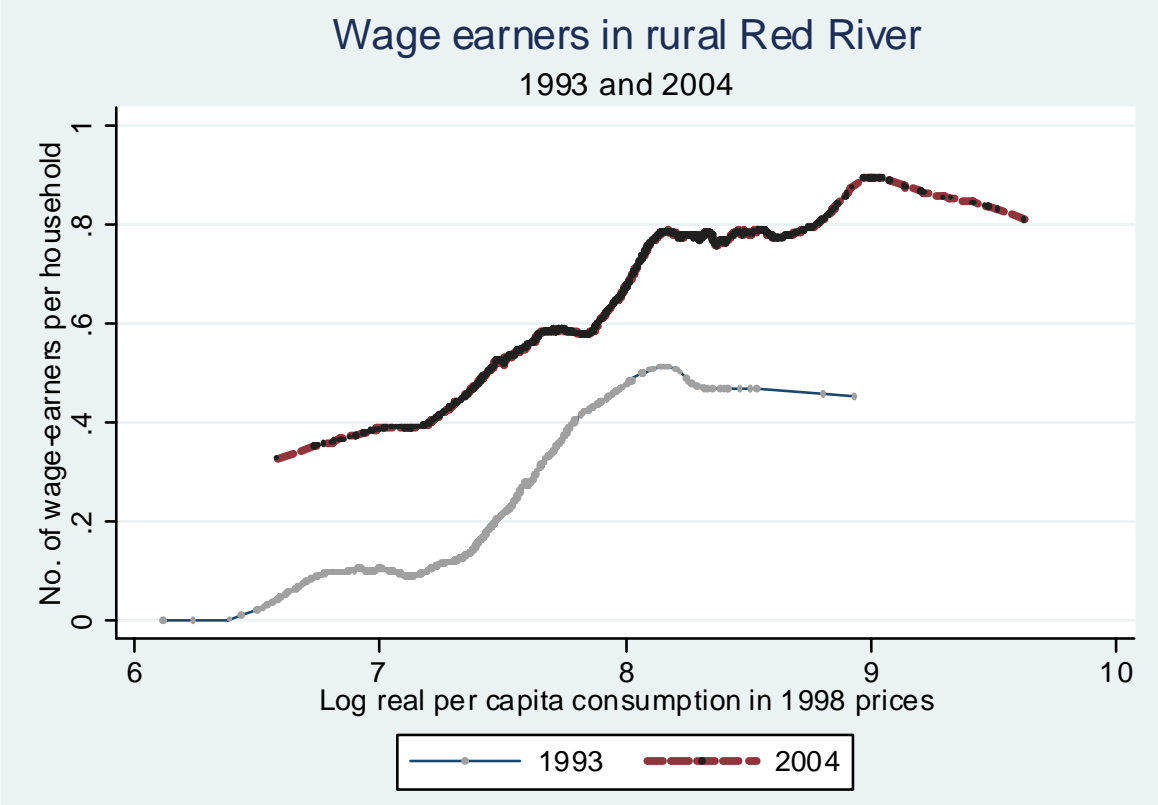

(b) Mekong Delta

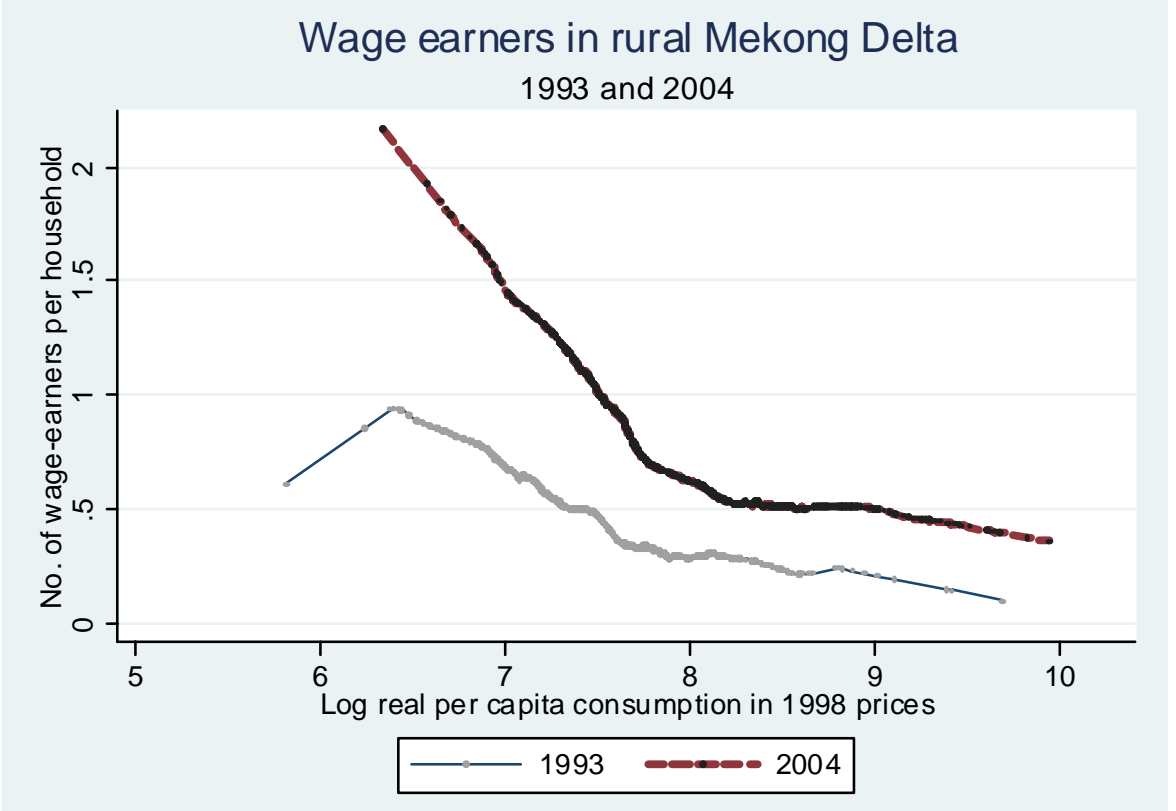


Figure 14: Formal credit utilization by consumption

(a) Farmers only

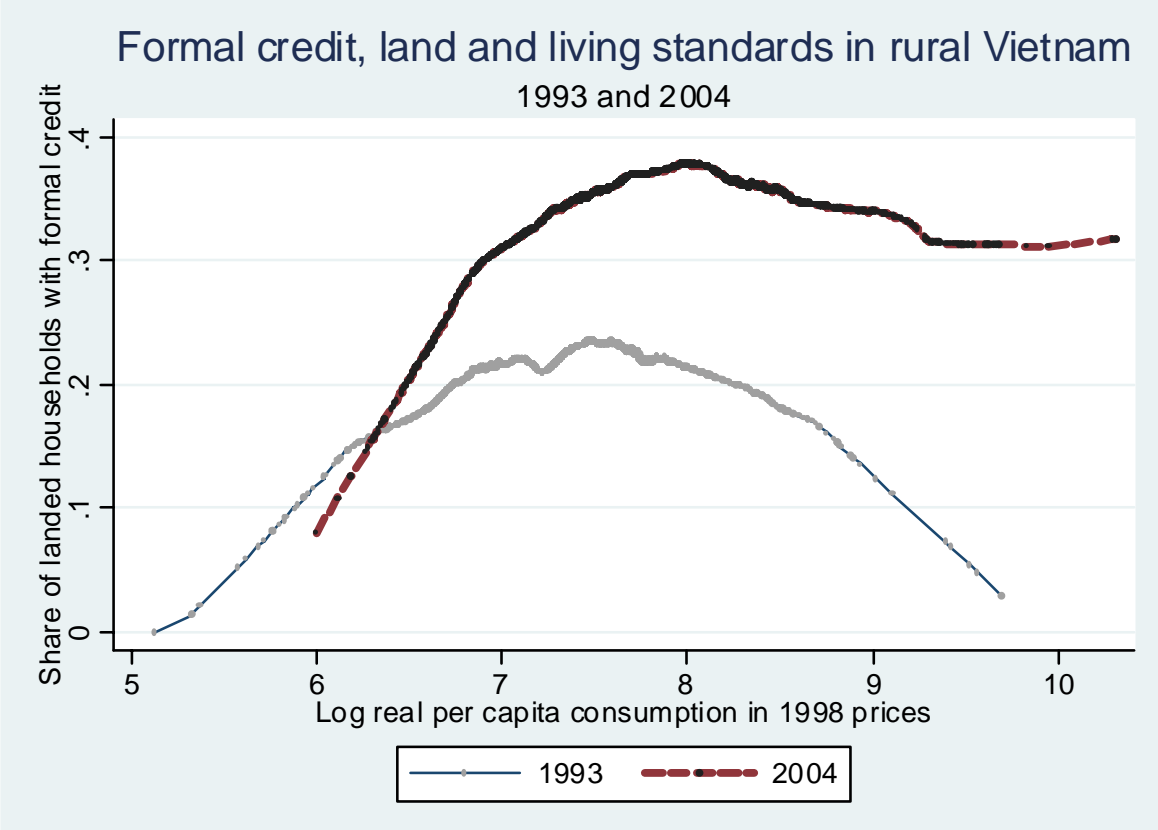

(b) Landless households only 